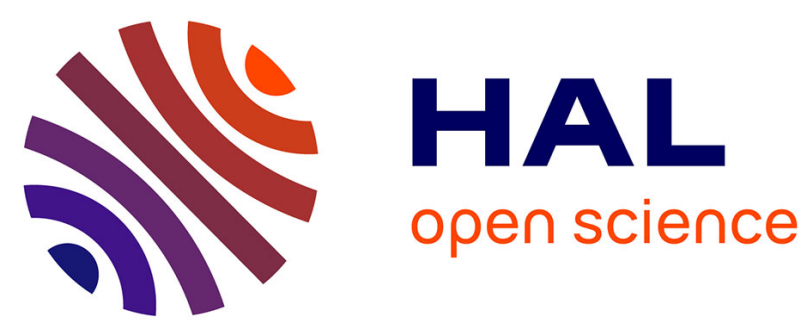

\title{
Cocoa Butter Saturated with Supercritical Carbon Dioxide: Measurements and Modelling of Solubility, Volumetric Expansion, Density and Viscosity
}

Brice Calvignac, Élisabeth Rodier, Jean-jacques Letourneau, Pedro Miguel Almeida dos Santos, Jacques Fages

\section{To cite this version:}

Brice Calvignac, Élisabeth Rodier, Jean-jacques Letourneau, Pedro Miguel Almeida dos Santos, Jacques Fages. Cocoa Butter Saturated with Supercritical Carbon Dioxide: Measurements and Modelling of Solubility, Volumetric Expansion, Density and Viscosity. International Journal of Chemical Reactor Engineering, 2010, 8 (1), pp.A73. 10.2202/1542-6580.2191 . hal-01142083

\section{HAL Id: hal-01142083 https://imt-mines-albi.hal.science/hal-01142083}

Submitted on 14 Apr 2015

HAL is a multi-disciplinary open access archive for the deposit and dissemination of scientific research documents, whether they are published or not. The documents may come from teaching and research institutions in France or abroad, or from public or private research centers.
L'archive ouverte pluridisciplinaire HAL, est destinée au dépôt et à la diffusion de documents scientifiques de niveau recherche, publiés ou non, émanant des établissements d'enseignement et de recherche français ou étrangers, des laboratoires publics ou privés. 


\title{
INTERNATIONAL JOURNAL OF CHEMICAL REACTOR ENGINEERING
}

\section{Cocoa Butter Saturated with Supercritical Carbon Dioxide: Measurements and Modelling of Solubility, Volumetric Expansion, Density and Viscosity}

\author{
Brice Calvignac* $^{*} \quad$ Elisabeth Rodier ${ }^{\dagger} \quad$ Jean-Jacques Letourneau $^{\ddagger}$ \\ Pedro Miguel Almeida dos Santos** Jacques Fages ${ }^{\dagger \dagger}$
}

\footnotetext{
*Université de Toulouse, brice.calvignac@mines-albi.fr

†Université de Toulouse, elisabeth.rodier@mines-albi.fr

†Université de Toulouse, letourne@mines-albi.fr

**Université de Toulouse, pedro.masantos@gmail.com

${ }^{\dagger \dagger}$ Université de Toulouse, jacques.fages@ mines.albi.fr ISSN 1542-6580

Copyright (c)2010 The Berkeley Electronic Press. All rights reserved.
} 


\title{
Cocoa Butter Saturated with Supercritical Carbon Dioxide: Measurements and Modelling of Solubility, Volumetric Expansion, Density and Viscosity*
}

\author{
Brice Calvignac, Elisabeth Rodier, Jean-Jacques Letourneau, Pedro Miguel \\ Almeida dos Santos, and Jacques Fages
}

\begin{abstract}
The use of supercritical carbon dioxide technology for lipid processing has recently developed at the expense of traditional processes. For designing new processes the knowledge of thermophysical properties is a prerequisite. This work is focused on the characterization of physical and thermodynamic properties of $\mathrm{CO}_{2}$-cocoa butter (CB) saturated mixture. Measurements of density, volumetric expansion, viscosity and $\mathrm{CO}_{2}$ solubility were carried out on $\mathrm{CB}$-rich phase at 313 and $353 \mathrm{~K}$ and pressures up to $40 \mathrm{MPa}$. The experimental techniques have previously been compared and validated. Density measurements of $\mathrm{CB}$ and $\mathrm{CB}$ saturated with $\mathrm{CO}_{2}$, were performed using the vibrating tube technology at pressures ranging from 0.1 to $25 \mathrm{MPa}$. Experimental values correlated well with the modified Tait equation. $\mathrm{CO}_{2}$ solubility measurements were coupled to those of density in the same pressures ranges. At $25 \mathrm{MPa}$, the solubility of $\mathrm{CO}_{2}$ is 31.4 $\%$ and $28.7 \%$ at 313 and $353 \mathrm{~K}$. Phase behaviour was investigated using a view cell in order to follow the expansion of the $\mathrm{CB}$-rich phase with the rise in pressure. Volumetric expansion up to $47 \%$ was measured and correlated to the $\mathrm{CO}_{2}$ solubility. Phase inversion was observed at $313 \mathrm{~K}$ and $40 \mathrm{MPa}$. Lastly, we developed an innovative falling ball viscometer for high pressure measurements. Viscosity measurements were carried out up to $25 \mathrm{MPa}$ showing a viscosity reduction up to 90 $\%$ upon $\mathrm{CO}_{2}$ dissolution. These results were correlated with two empirical models. A new model here presented, was favourably compared with the Grunberg and Nissan model. All the experimental results are consistent with the available literature data for the $\mathrm{CB}-\mathrm{CO}_{2}$ mixture and other fat systems. This work is a new

\footnotetext{
*The authors are affiliated with the Université de Toulouse, Ecole des Mines d'Albi-Carmaux, Centre RAPSODEE FRE-CNRS 3213. The authors would like to acknowledge the financial support of CNRS (France) and the Carnot Institute M.I.N.E.S. (France). Gerkens Cacao (The Netherlands) is also gratefully acknowledged for the cocoa butter supply for the experiments.
} 
contribution to the characterization of physical and thermodynamic behaviour of fats in contact with $\mathrm{CO}_{2}$ which is necessary to design supercritical fluid processes for fats processing.

KEYWORDS: phase equilibrium, density, viscosity, modelling, cocoa butter, supercritical $\mathrm{CO}_{2}$ 


\section{Introduction}

Supercritical fluid processes are emerging technologies, which are clean and efficient alternative to conventional methods for fats and oils processing (Temelli, 2009). Supercritical carbon dioxide $\left(\mathrm{SC}-\mathrm{CO}_{2}\right)$ is commonly used and has become the solvent of choice for food, cosmetic and pharmaceutical industries, because of its non toxicity and its moderate critical properties (critical pressure: $7.38 \mathrm{MPa}$, critical temperature: $304.35 \mathrm{~K}$ ). Several studies over the last twenty years were dedicated to the supercritical extraction and fractionation of fats and oils of vegetable and animal origin. These applications could allow isolating added value lipids such as polyunsaturated fatty acids, tocopherols, carotenoids, phytosterols known for their health benefits (Sahena et al., 2009).

Cocoa butter $(\mathrm{CB})$ is a complex natural product composed of different types of triglycerides (TG) whose proportions vary according to its geographic origin (Chaiseri and Dimick, 1989). The most abundant ones are monounsaturated TG, which have the unsaturated fatty acid in the 2-position and saturated fatty acids in 1- and 3-position: 1-palmitoyl-2-oléoyl-3stéaroylglycérol (POS), 1,3stéaroyl-2-oléoylglycérol (SOS) and 1,3-palmitoyl-2oléoylglycérol (POP). CB is the fat of cocoa and it is used in the chocolate manufacturing process. Considering chocolate crystallization, the $\mathrm{TG}$ are mainly responsible of the polymorphic transitions at different temperatures. Indeed, the CB can crystallize in six different polymorphic forms (in order of increasing stability): I (melting point, 286.1-290.6 K), II (290.8-292.9 K), III (295.4-297.5 K), IV (299.4-300.9 K), V (303.7-307.4 $\mathrm{K})$ and VI (306.8-307.1 K). In addition, the polymorphic fraction of each form has a direct influence on the quality and the characteristics of the end product.

Supercritical crystallisation of CB has already been investigated (Letourneau et al., 2005; Perva-Uzunalic et al., 2008) and leaded to the successful generation of form V crystals. Venter et al. (2006) investigated the gas assisted mechanical expression (GAMSE) process consisting in pressing mechanically cocoa nibs saturated with supercritical $\mathrm{CO}_{2}$, in order to produce $\mathrm{CB}$. The supercritical fractionation of $\mathrm{CB}$ has not yet been fully investigated though Bhaskar et al. (1996) were the first to show that it was feasible. They used the difference of solubility in $\mathrm{CO}_{2}$ of the three predominant triglycerides contained in $\mathrm{CB}$.

This work is the preliminary step of a study aiming at a new clean recrystallization / fractionation process of $\mathrm{CB}$ assisted by $\mathrm{SC}-\mathrm{CO}_{2}$. As any other process design, it requires the knowledge of properties of the $\mathrm{CO}_{2}-\mathrm{CB}$ mixture such as reciprocal solubility, phase equilibria behaviour, density and viscosity of phases. They are necessary to go further in the understanding of the phenomena implied in the processing of lipids. Yet, there is a lack of such physical and thermodynamic properties data in the literature. 
This study has been limited to the liquid phase composed of melted $\mathrm{CB}$ saturated with $\mathrm{CO}_{2}$ and for which we carried out experimental and modelling work of the density and viscosity. Moreover, we investigated the phase equilibria behaviour by the determination of the $\mathrm{CO}_{2}$ solubility and the volumetric expansion of $\mathrm{CB}$ saturated with $\mathrm{CO}_{2}$. These characterization techniques were validated by comparing the measured properties of $\mathrm{CO}_{2}$-DMSO mixture with available literature data (Calvignac et al., 2009a).

\section{Material and Methods}

\subsection{Materials}

Cocoa butter was obtained from Gerkens Cacao (Wormer, The Netherlands). It comes from the same supplier and the same origin as the cocoa butter used by Venter et al (2006). Its composition is given in Table 1. Carbon dioxide (purity $99.995 \%$ ) was purchased from Air liquide S.A. (Paris, France). Pure water was obtained by ELGA purification system.

Table 1. Composition in triglycerides of cocoa butter. O, L, P, S and A stand respectively for the following fatty acids: oleic, linoleic, palmitic, stearic and arachidic

\begin{tabular}{|c|c|}
\hline Triglycerides & Composition (\%) \\
\hline OLO & 0.4 \\
\hline PLP & 0.4 \\
\hline OOO & 1.5 \\
\hline POO & 0.3 \\
\hline PLS & 1.8 \\
\hline POP & 18.0 \\
\hline POS & 38.2 \\
\hline SOS & 26.0 \\
\hline SOO & 1.8 \\
\hline SLS & 2.4 \\
\hline PPS & 4.7 \\
\hline PSS & 3.1 \\
\hline SOA & 1.1 \\
\hline SSS & 0.3 \\
\hline
\end{tabular}




\subsection{Experimental set-up and procedures}

\subsubsection{Solubility and density measurements}

A photograph and a schematic diagram of the static analytical device for VLE and density measurements are shown in Figure 1 and 2.

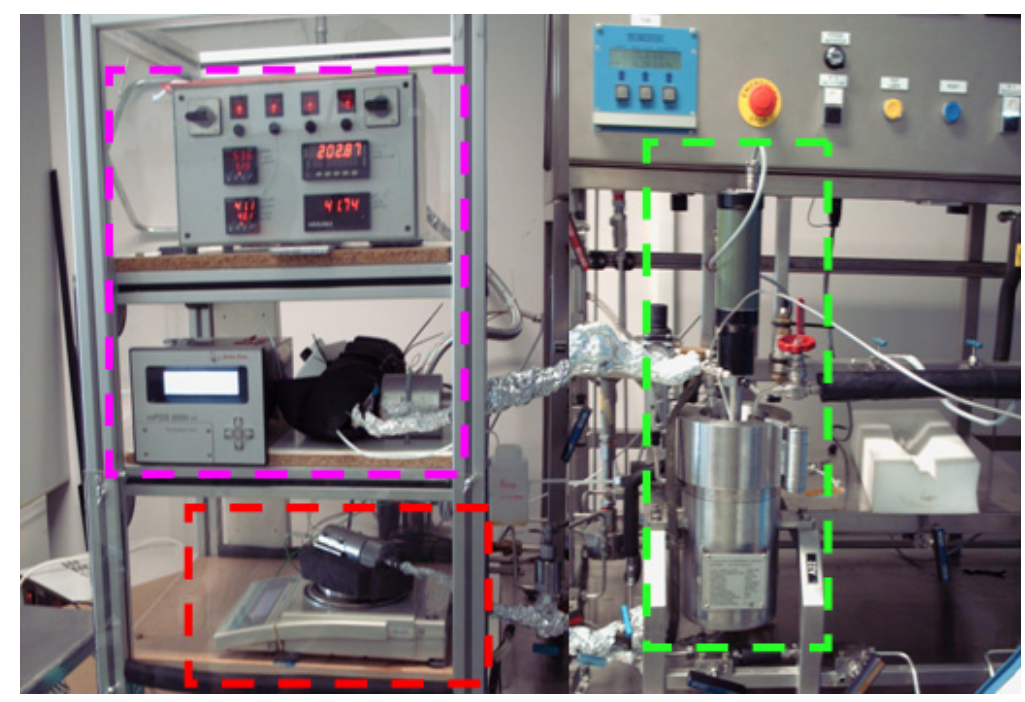

Figure 1. Photograph of the experimental device

The apparatus has been designed to carry out investigations under high pressure and high temperature, respectively up to $35 \mathrm{MPa}$ and $473 \mathrm{~K}$. It is composed of three mains parts: a VLE device, a gravimetric analysis device and a densimeter. A similar device for VLE measurements was used in a previous study dedicated to the development and to the validation of this experimental set-up (Calvignac et al., 2009a).

The stainless steel autoclave (1), which capacity is $500 \mathrm{~mL}$ (Xenard, France), was previously loaded with $250 \mathrm{~mL}$ of melted $\mathrm{CB}$ and heated to the desired temperature. Liquid $\mathrm{CO}_{2}$ was pumped by a high pressure membrane pump (Lewa, France) (2) and preheated by a heat exchanger (Separex, France) (3) before feeding the autoclave equipped with a stirring mechanical device (Topindustrie, France). Then, a syringe pump (Model ISCO 260D) (4) previously filled with $\mathrm{CO}_{2}(260 \mathrm{~mL})$ and operating at the same pressure and temperature conditions as the autoclave, was used to maintain the equilibrium of the studied mixture. 


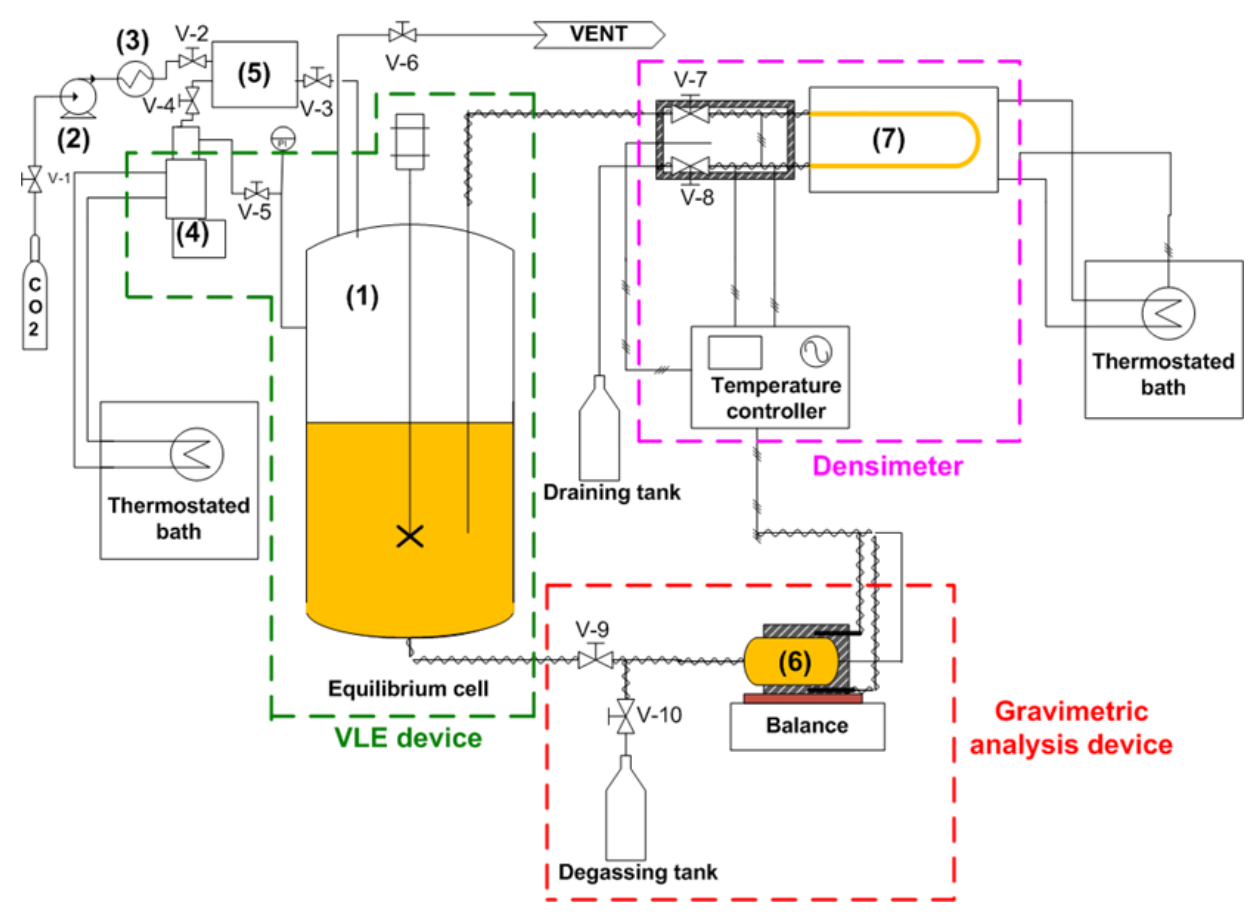

Figure 2. Schematic diagram of the VLE apparatus

The pressure and temperature set-up of the VLE apparatus (autoclave and syringe pump) were kept constant respectively within $\pm 0.01 \mathrm{MPa}$ and $\pm 0.1 \mathrm{~K}$. A buffer storage tank (5) is connected to the $\mathrm{CO}_{2}$ feed pipe, to the equilibrium autoclave and to the syringe pump. Once the equilibrium was reached, pressure in the tank was increased of $5 \mathrm{MPa}$ above the equilibrium pressure in order to ensure a pressure drop compensation when valve V-9 was opened to make gravimetric analysis.

Then, the compensation operation was achieved by the membrane pump. The $\mathrm{CO}_{2}$ flow compensation was fixed to $2 \mathrm{~kg} \cdot \mathrm{h}^{-1}$ in order to minimize the pressure drop $\left(\Delta \mathrm{P}_{\max }=0.5 \mathrm{MPa}\right)$ manually controlled by $\mathrm{V}-7$. Cell temperature was kept constant by means of a PID controller within $\pm 0.1 \mathrm{~K}$. This stainless steel measurement cell (Top-industrie, France) (6) was previously weighed empty and placed on a high precision balance (Sartorius Model LA3200B), and it was then used to sample $50 \mathrm{~mL}$ of the liquid phase. The balance used allows gravimetric analyses within $\pm 0.01 \mathrm{~g}$. Moreover, density measurements were carried out in the same time with an accuracy of $\pm 0.01 \mathrm{~kg} . \mathrm{m}^{-3}$. Thus, valve $\mathrm{V}-7$ was opened to refill the vibrating U-tube densimeter (Anton-Paar, model DMA-HPM) (7). Temperature in the vibrating U-tube was precisely controlled by a thermostated bath within $\pm 0.01 \mathrm{~K}$ and pressure was measured by a transducer (Model Druck PTX 611) with an accuracy of $\pm 0.001 \mathrm{MPa}$. 
Volume within the loop remaining small, equilibrium was hardly perturbed and reached quickly. All pipes of the apparatus were thermally controlled within $\pm 0.1 \mathrm{~K}$.

Once all parameters (pressure, temperature, mass) were stable, they were recorded and valve V-9 was closed to isolate the cell. The valve V-10 was then opened and the mixture was slowly degassed in order to recover cocoa butter and consequently to deduce the solubility of $\mathrm{CO}_{2}$ in the liquid phase. Then, after each experiment, the gravimetric analysis device was cleaned.

In this work, the solubility of $\mathrm{CO}_{2}$ was defined as the mass percentage of $\mathrm{CO}_{2}\left(X_{\mathrm{CO} 2}\right)$ contained in the liquid phase rich in $\mathrm{CB}$, according to:

$$
X_{C O 2}(\%)=\frac{m_{\text {mixture }}-m_{C B}}{m_{\text {mixture }}} \cdot 100
$$

The vibrating U-tube densimeter was previously calibrated with water and $\mathrm{CO}_{2}$ for all the pressure and temperature range of the VLE measurements. The principle of density measurements using this technology is based on the dependence of the vibration period of the U-bended part of the tube according to the filling fluid mass and the U-tube mass. The behaviour of the vibrating tube can be compared to an undamped spring-mass, defined by its oscillation period, $\tau$ (s), such as:

$$
\tau=2 \pi \sqrt{\frac{m_{o}+V \rho}{D}}
$$

where $m_{0}$ is the mass of the empty U-tube $(\mathrm{kg}), V$ is the internal volume of the tube $\left(\mathrm{m}^{3}\right), \rho$ is the density of the fluid $\left(\mathrm{kg} \cdot \mathrm{m}^{-3}\right)$ and $D$ is the spring constant $\left(\mathrm{N} . \mathrm{m}^{-}\right.$ $\left.{ }^{1}\right)$. Rearrangement of this equation leads to a simple relation giving the density commonly used in the vibrating tube technology:

$\rho=A \tau^{2}-B$

The apparatus parameters $A$ and $B$ are defined from measured oscillation periods at fixed pressure and temperature conditions and known densities of water (Wagner and Pruss, 2002) and carbon dioxide (Span and Wagner , 1996), such as:

$$
A=\frac{\rho_{\mathrm{H}_{2} \mathrm{O}(T, P)}-\rho_{\mathrm{CO}_{2}(T, P)}}{\left(\tau_{\mathrm{H}_{2} \mathrm{O}(T, P)}\right)^{2}-\left(\tau_{\mathrm{CO}_{2}(T, P)}\right)^{2}}
$$


$B=\frac{\left(\tau_{\mathrm{CO}_{2}(T, P)}\right)^{2} \rho_{\mathrm{H}_{2} \mathrm{O}(T, P)}-\left(\tau_{\mathrm{H}_{2} \mathrm{O}(T, P)}\right)^{2} \rho_{\mathrm{CO}_{2}(T, P)}}{\left(\tau_{\mathrm{H}_{2} \mathrm{O}(T, P)}\right)^{2}-\left(\tau_{\mathrm{CO}_{2}(T, P)}\right)^{2}}$

The measured oscillation periods and consequently the measured densities are very sensitive to pressure and temperature variations. Thanks to the compensation of the syringe pump (about $\pm 0.1 \mathrm{~mL} / \mathrm{min}$ ) and the good precision of the several heating devices of the VLE apparatus, the thermodynamic equilibrium can be easily reached and maintained. Each experimental point was performed at least three times with an overall precision of $\pm 0.60 \mathrm{~kg} \cdot \mathrm{m}^{-3}$.

The procedure for the density measurements of cocoa butter without carbon dioxide was the following: liquid cocoa butter was pumped by an ISCO syringe pump and injected into the densimeter.

\subsubsection{Volumetric expansion measurements}

A schematic diagram of the experimental device for volumetric expansion measurements is shown in Figure 3. The apparatus (Sitec, Switzerland) has been designed to perform experiments at pressures and temperatures up to, respectively, $50 \mathrm{MPa}$ and $473 \mathrm{~K}$. The experimental procedure has been validated previously (Calvignac et al., 2009a).

The cell measurement was equipped with a heating jacket and two opposite sapphire windows: one for lighting and the other for the visualization of the volumetric expansion using a digital camera. The stainless steel cell was a vertical hollow cylinder with a total volume of $93.89 \pm 0.10 \mathrm{ml}$ (including pipes). The pressure in the apparatus was kept constant within $\pm 0.1 \mathrm{MPa}$. The cell temperature was controlled precisely $( \pm 0.2 \mathrm{~K})$ with a thermostated bath by means of a PT100 temperature probe. In addition, a magnetic stirrer homogenised the mixture until the thermodynamic equilibrium was reached, that was at least one hour after stabilization of the pressure at constant temperature. The volumetric expansion measurement consisted in observing and recording the evolution of the liquid phase volume with pressure. This volume was calculated as a function of the height of liquid, which was obtained by the analysis of the captured images with the ImageJ software (National Institute of Health, USA). Note that the measurement of the height of liquid was estimated to be accurate within \pm 4 pixels. As for the determination of the volumetric expansion (E) of the liquid phase, an initial volume $\left(\mathrm{V}_{0}\right)$ of $\mathrm{CB}$ was introduced into the cell at given temperature $(\mathrm{T})$ and atmospheric pressure $\left(\mathrm{P}_{0}\right)$ by the syringe pump. Then, $\mathrm{CO}_{2}$ was introduced at the same temperature $(\mathrm{T})$ and pressure $(\mathrm{P})$ by the piston pump. The mixture was 
homogenised until all experimental parameters were stabilised (T, P and E) meaning that the thermodynamic equilibrium was reached.

Besides, the volumetric expansion of the liquid phase at $(\mathrm{T})$ and $(\mathrm{P})$ was defined by:

$E(\%)=\frac{V(T, P)-V_{0}\left(T, P_{0}\right)}{V_{0}\left(T, P_{0}\right)} \cdot 100$

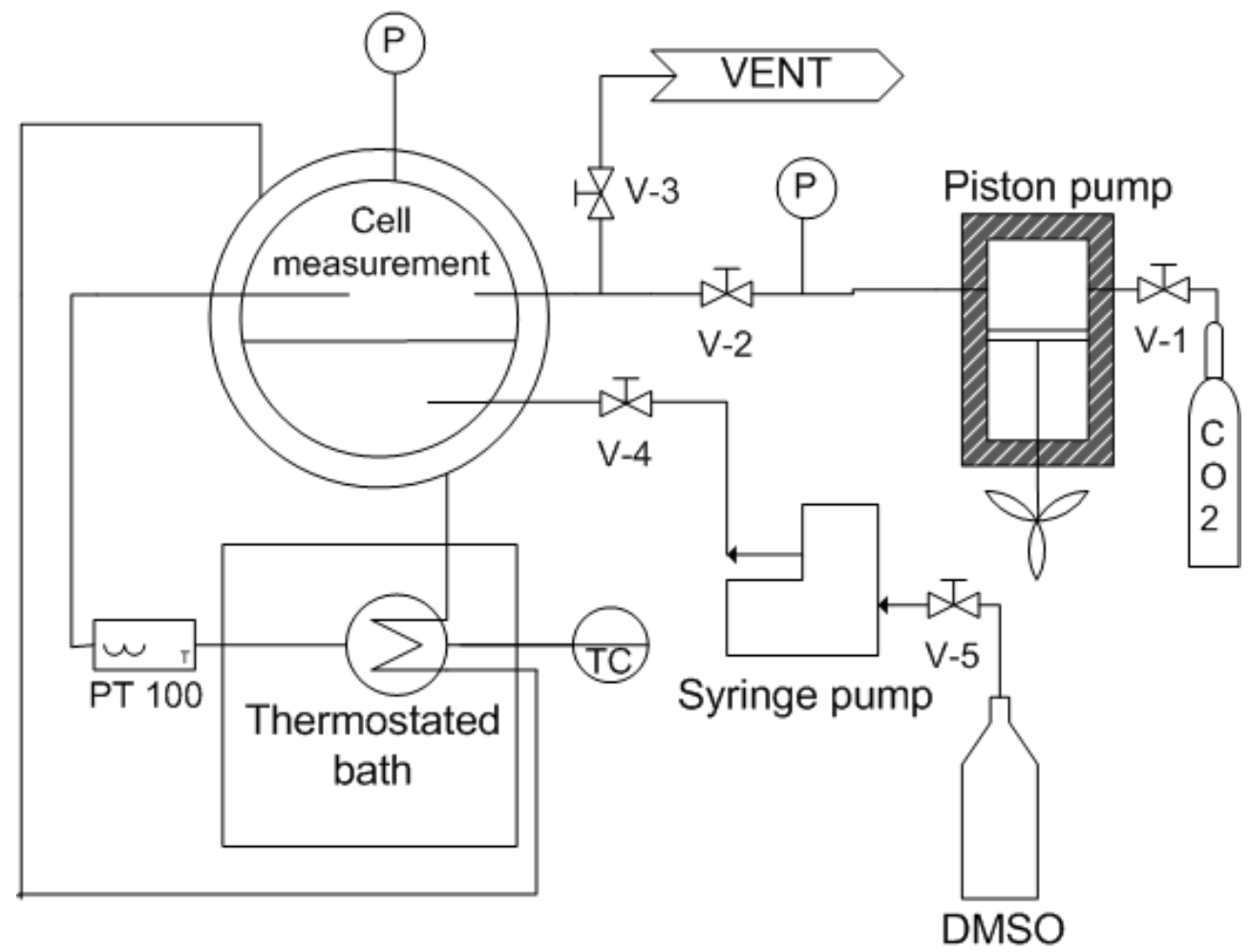

Figure 3. Schematic diagram of the apparatus for volumetric expansion measurements

\subsubsection{Viscosity measurements}

A schematic diagram of the falling body viscometer (FBV) is shown on Figure 4. The apparatus has been designed to perform experiments at pressures and temperatures up to, respectively $45 \mathrm{MPa}$ and $473 \mathrm{~K}$. The stainless steel autoclave with a capacity of 2.61 (Top-industrie, France) was previously loaded with CB 
and heated to the desired temperature. It was equipped with sapphire windows (SW) for visualization purpose using a cold lighting device and a high speed digital video camera (Photron, USA) connected to a computer. Liquid $\mathrm{CO}_{2}$ was pumped with a high pressure membrane pump (Lewa, France) and preheated by a heat exchanger (Separex, France) before flowing into the autoclave equipped with a mechanical stirrer (Top-industrie, France). Then, a syringe pump (ISCO Model 100HLX) previously filled with CB and operating at the same temperature as in the autoclave, adjusted the level of the liquid phase (because of its expansion) so as to immerge entirely the glass tube. The pressure and temperature set-up of the viscometer were kept constant within $\pm 0.1 \mathrm{MPa}$ and $\pm 0.1 \mathrm{~K}$.

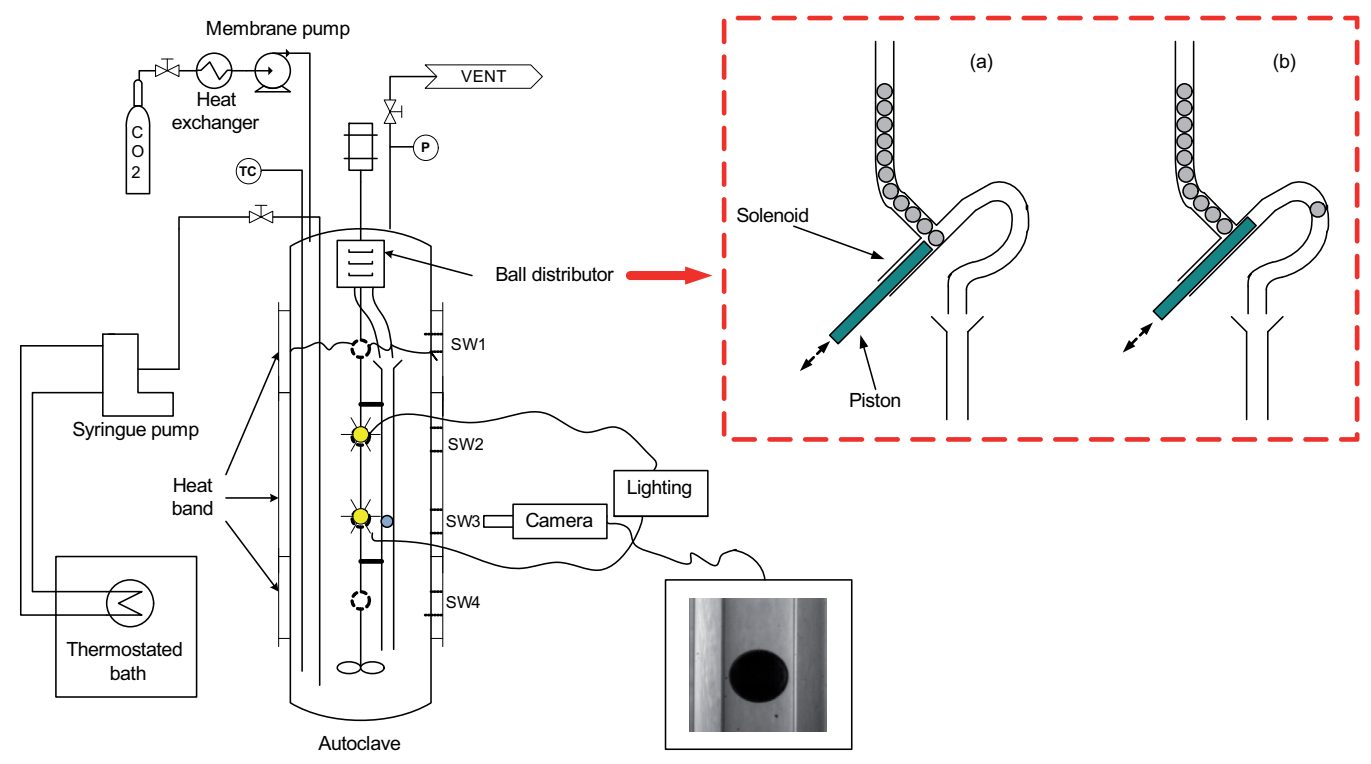

Figure 4. Schematic diagram of the high pressure viscometer

Once the equilibrium was reached, stirring was stopped and viscosity measurements were performed at constant pressure and temperature. Measurements consisted in recording through a window (SW3) the fall of an aluminium ball (2 $\mathrm{mm}$ diameter) in an open glass tube $(2.1 \mathrm{~mm}$ diameter and 20 $\mathrm{cm}$ length). The ball distributor allowed to release them one at a time by means of an electrical impulsion given to the solenoid (Figure 4(a) and 4(b)). The first ones were not considered and ensured the homogenization of the fluid in the tube, even if the whole volume in the autoclave was previously homogenized during 24 hours.

A detailed description of the methodology for viscosity determination by CFD calculation under COMSOL Multiphysics ${ }^{\circledR}$ has recently been reported 
elsewhere (Calvignac et al., 2009b). Calculations were based on the laminar Navier-Stokes model for a newtonian fluid and on the continuity equation for an incompressible fluid, both in steady-state conditions. The key experimental parameters for these calculations were the ball terminal velocity, the fluid density and the ball density. The terminal velocities were obtained by the analysis of the images of a high-speed digital video using software developed with the Image Processing Toolbox from Matlab ${ }^{\circledR}$. The fluid density data were taken from the measurements done in this work. The density of the aluminium ball, $2723.3 \pm 0.9$ $\mathrm{kg} . \mathrm{m}^{-3}$, was previously determined by a He pycnometer. This FBV allowed measuring viscosities down to $2 \mathrm{mPa}$.s. This limitation is due to the restricted operating conditions of the technique and to the calculation model hypotheses: transparent medium, ball velocity measurable below $35 \mathrm{~mm} \cdot \mathrm{s}^{-1}$ and laminar and steady flow.

Prior to these measurements, we performed rheological measurements at atmospheric pressure on $\mathrm{CB}$ with a dynamic rotational rheometer (Haake Rheostress 600 , Thermo electron, Germany) with a cone-plate geometry ( $1^{\circ}$ angle cone and $60 \mathrm{~mm}$ diameter). They allowed measuring viscosity of CB from 313 to $353 \mathrm{~K}$. Measurements were compared to the results obtained with the falling body viscometer (FBV) and to the literature data.

\section{Results and Discussion}

\subsubsection{Solubility of $\mathrm{CO}_{2}$}

Solubility of $\mathrm{CO}_{2}$ in $\mathrm{CB}$ was measured at 313 and $353 \mathrm{~K}$. Results obtained are presented in Table 2 and Figure 5. Several investigators have also studied the phase equilibrium behaviour of $\mathrm{CB}-\mathrm{CO}_{2}$ binary at $313 \mathrm{~K}$ and $353 \mathrm{~K}$ (Kokot et al., 1999; Venter et al., 2007) and the data are presented in Figure 6 and 7. Kokot et al. determined the mutual solubility of $\mathrm{CB}$ and $\mathrm{CO}_{2}$ using a static analytical method which consisted in sampling the heavy (rich in $\mathrm{CB}$ ) and the light phase (rich in $\mathrm{CO}_{2}$ ). Each sample was degassed and the amount of $\mathrm{CO}_{2}$ was measured by a flow meter while the amount of $\mathrm{CB}$ was weighed. Venter et al. used two static analytical methods to determine the solubility of $\mathrm{CO}_{2}$ in $\mathrm{CB}$. The first one is identical to those used by Kokot et al. The second one consists in sampling the heavy phase in a cell and washing the recovered $\mathrm{CB}$ with petroleum ether in order to ensure that there is not residual dissolved $\mathrm{CO}_{2}$.

The solubility of $\mathrm{CO}_{2}$ increases with pressure whereas it decreases with the temperature (Figure 5). At 313 and $353 \mathrm{~K}$, the solubility reaches respectively a maximum of $31.4 \%$ and $28.7 \%$. Each data point in Figure 5 represents the average of measurements, which were repeated at least three times. The maximum uncertainty is about $2.7 \%$ at $353 \mathrm{~K}$ and is due the random 
experimental errors generated by the difficulty to keep constant pressure and temperature during the sampling operation.

Table 2. Solubility of $\mathrm{CO}_{2}$ in $\mathrm{CB}$ at different pressures at 313 and $353 \mathrm{~K}$

\begin{tabular}{|c|c|c|c|}
\hline \multicolumn{2}{|c|}{$313 \mathbf{~ K}$} & \multicolumn{2}{c|}{$353 \mathbf{~ K}$} \\
\hline $\mathbf{P}$ (MPa) & $\mathbf{x}_{\mathbf{C O 2} 2} \mathbf{( \% )}$ & $\mathbf{P} \mathbf{( M P a )}$ & $\mathbf{x}_{\mathbf{C O} 2} \mathbf{( \% )}$ \\
\hline 5.31 & $11.3 \pm 1.1$ & 5.11 & $5.7 \pm 2.7$ \\
\hline 10.19 & $24.1 \pm 1.0$ & 10.25 & $17.2 \pm 2.1$ \\
\hline 15.16 & $27.5 \pm 1.3$ & 15.28 & $19.3 \pm 1.8$ \\
\hline 20.16 & $29.6 \pm 1.1$ & 20.29 & $24.4 \pm 2.3$ \\
\hline 25.19 & $31.4 \pm 1.0$ & 25.24 & $28.7 \pm 2.7$ \\
\hline
\end{tabular}

$313 \mathrm{~K}$ o $353 \mathrm{~K}$

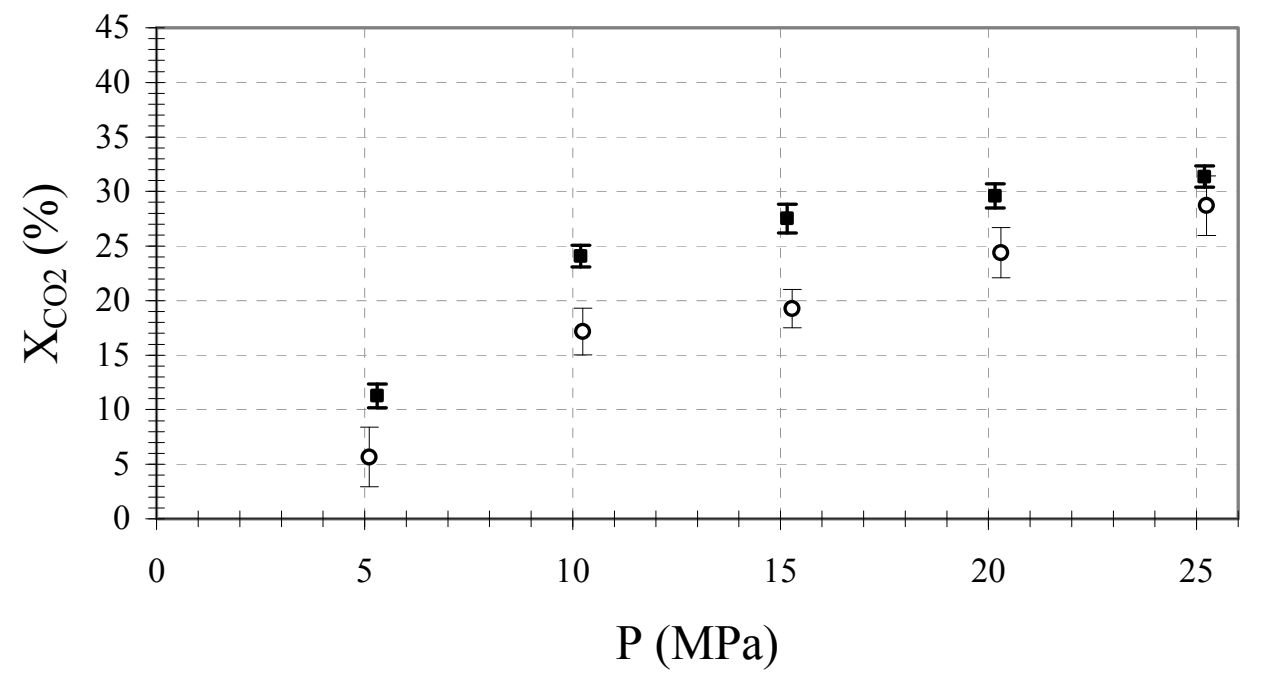

Figure 5. Evolution of $\mathrm{CO}_{2}$ solubility in cocoa butter at 313 and $353 \mathrm{~K}$

Comparisons between our experimental data and literature ones are shown in Figure 6 and 7. For both isotherms, ours results are in good agreement with those of Venter et al. The mean deviation (MD) for results obtained with the first method is respectively $1.1 \%$ and $1.2 \%$ at 313 and $353 \mathrm{~K}$. With regard to the second method, MD is respectively about $3.7 \%$ and $0.8 \%$ at 313 and $353 \mathrm{~K}$. However, for both isotherms, there are significant discrepancies with data obtained by Kokot et al. above $7 \mathrm{MPa}(\mathrm{MD}=10.7 \%$ at $313 \mathrm{~K}$ and $12.7 \%$ at 353 $\mathrm{K})$. It is important to note that our $\mathrm{CB}$ is provided by the same manufacturer than Venter et al. The origin of CB used by Kokot et al. being different, it might 
influence its behaviour in contact with $\mathrm{CO}_{2}$. We can suppose that the difference in $\mathrm{TG}$ composition and in the nature of minor components affect the $\mathrm{CO}_{2}$ solubility in $\mathrm{CB}$.

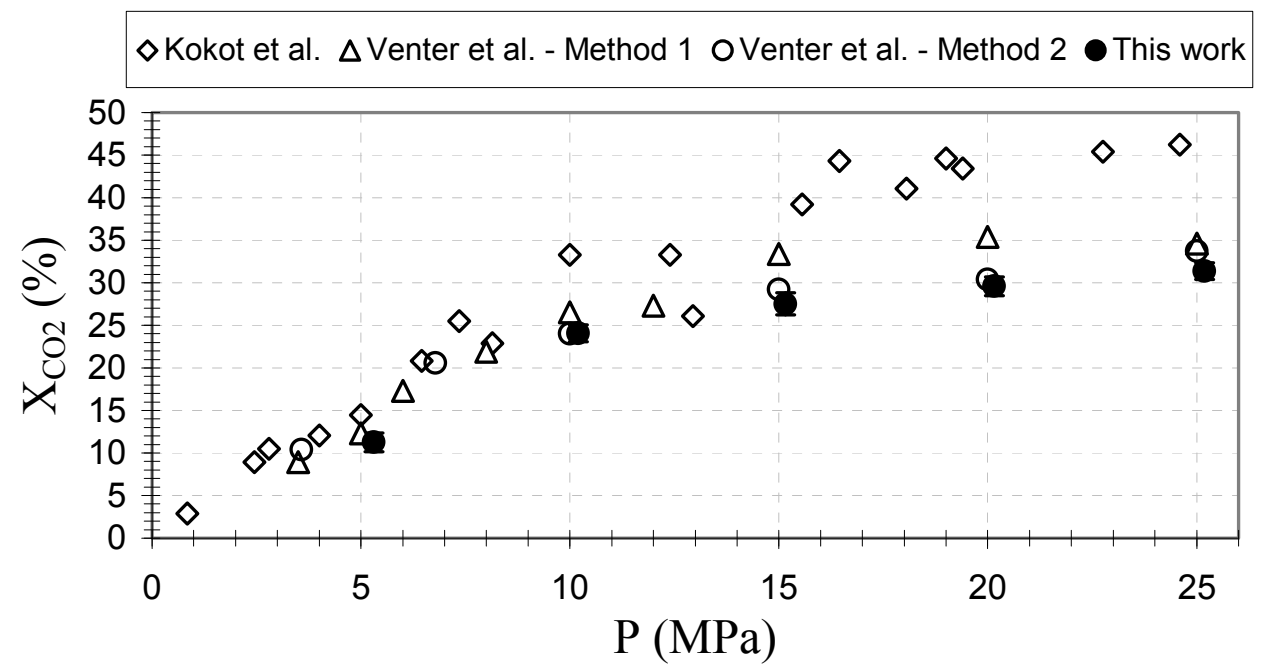

Figure 6. Comparison of $\mathrm{CO}_{2}$ solubility in cocoa butter with literature data at $313 \mathrm{~K}$

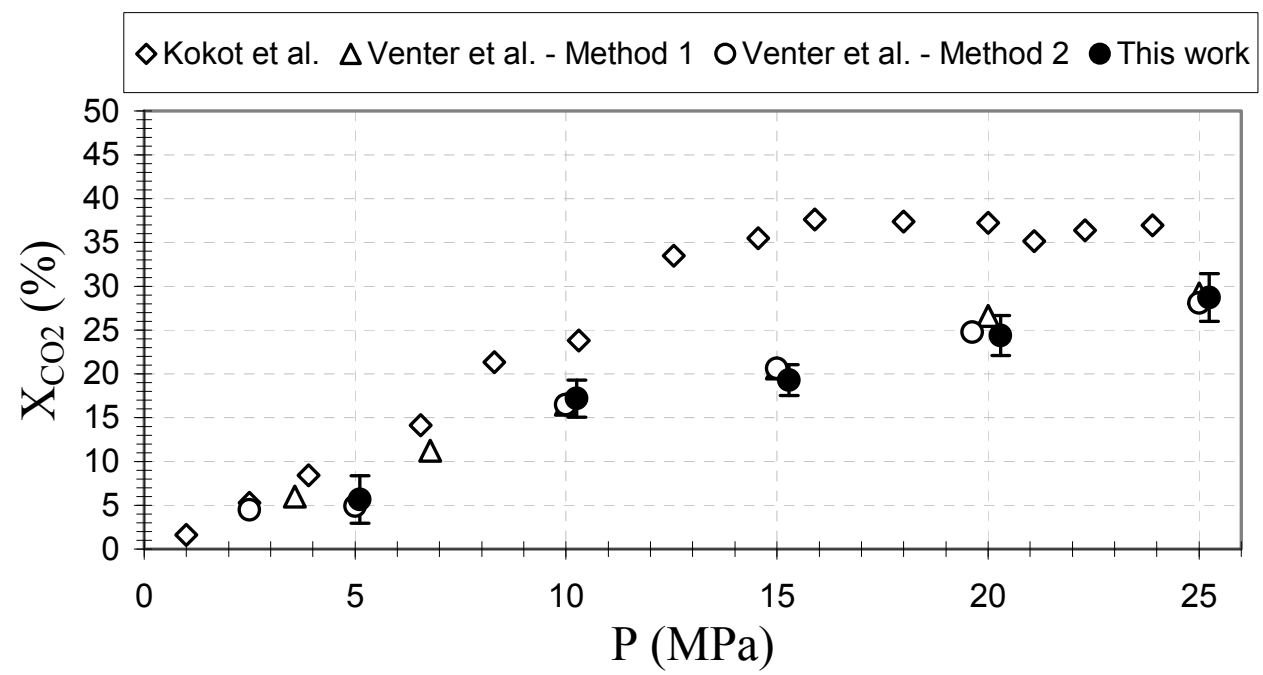

Figure 7. Comparison of $\mathrm{CO}_{2}$ solubility in cocoa butter with literature data at $353 \mathrm{~K}$ 


\subsubsection{Density}

Densities were measured for $\mathrm{CB}$ and $\mathrm{CO}_{2}$-saturated $\mathrm{CB}$ mixture for pressure ranging from 0.1 to $25 \mathrm{MPa}$ and at $313.15,323.15$ and $353.15 \mathrm{~K}$. Results are presented in Table 3 and Figure 8.

Table 3. Density of cocoa butter (CB) and $\mathrm{CB}-\mathrm{CO}_{2}$ mixture at 313,323 and $353 \mathrm{~K}$

\begin{tabular}{|c|c|c|c|c|c|c|}
\hline & \multicolumn{2}{|c|}{$313 \mathrm{~K}$} & \multicolumn{2}{|c|}{$323 \mathrm{~K}$} & \multicolumn{2}{|c|}{$353 \mathrm{~K}$} \\
\hline & P (MPa) & $\rho\left(\mathrm{kg} \cdot \mathrm{m}^{-3}\right)$ & P (MPa) & $\rho\left(\mathrm{kg}^{\prime} \mathrm{m}^{-3}\right)$ & P (MPa) & $\rho\left(\mathrm{kg} \cdot \mathrm{m}^{-3}\right)$ \\
\hline \multirow{6}{*}{ CB } & 0.10 & 894.76 & 0.10 & 888.54 & 0.10 & 868.14 \\
\hline & 5.17 & 897.48 & 5.18 & 891.48 & 5.26 & 871.70 \\
\hline & 10.12 & 899.50 & 10.15 & 892.52 & 10.28 & 874.99 \\
\hline & 15.19 & 901.84 & 15.14 & 897.68 & 15.28 & 877.06 \\
\hline & 20.12 & 905.01 & 20.07 & 900.06 & 20.27 & 879.98 \\
\hline & 25.07 & 908.08 & 25.01 & 902.76 & 25.24 & 883.65 \\
\hline \multirow{6}{*}{$\mathrm{CB}-\mathrm{CO}_{2}$ mixture } & 0.10 & 894.76 & 0.10 & 888.54 & 0.10 & 868.14 \\
\hline & 5.41 & 904.70 & 5.19 & 897.22 & 5.21 & 872.87 \\
\hline & 10.29 & 912.33 & 10.11 & 902.26 & 10.35 & 876.32 \\
\hline & 15.26 & 920.87 & 15.23 & 910.55 & 15.38 & 881.04 \\
\hline & 20.26 & 924.38 & 20.16 & 915.78 & 20.39 & 885.34 \\
\hline & 25.29 & 931.48 & 25.08 & 921.62 & 25.34 & 890.22 \\
\hline
\end{tabular}

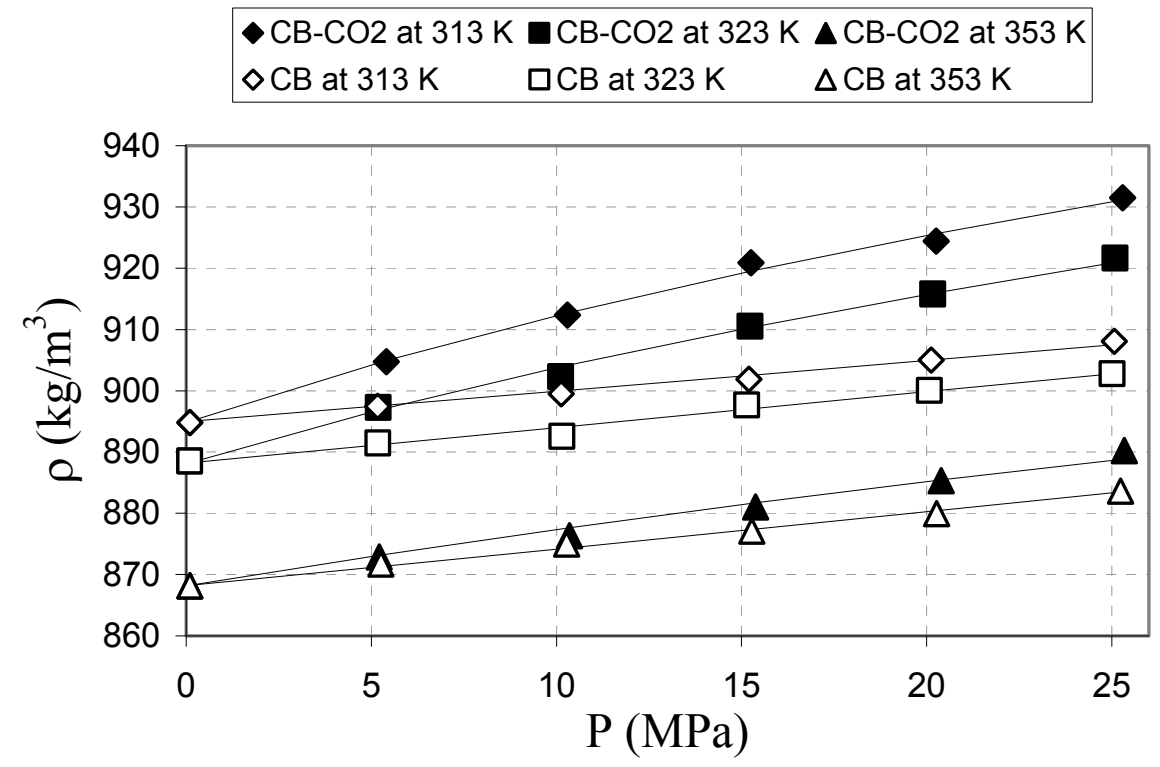

Figure 8. Density of cocoa butter (CB) and $\mathrm{CB}$ saturated with $\mathrm{CO}_{2}$ at 313,323 and $353 \mathrm{~K}$ and pressures up to $25 \mathrm{MPa}$ 
The density of cocoa butter decreases linearly with the temperature at constant pressure and conversely the density increases linearly with the pressure at constant temperature. The same behaviour for density of $\mathrm{CB}-\mathrm{CO}_{2}$ is observed but the slope of density increase with the pressure differs according to the temperature. However, it is more interesting to plot the $\mathrm{CB}-\mathrm{CO}_{2}$ mixture density versus the $\mathrm{CO}_{2}$ solubility, since there are data available for comparison in the literature (Figure 9). At $353 \mathrm{~K}$, the density increases linearly with $\mathrm{CO}_{2}$ solubility, so is the case for the results of Venter et al. (2007) at the same temperature. In addition, at $313 \mathrm{~K}$, we can compare our results with those of Seifreid and Temelli (2009) who measured the density of fish oil and correlated it to the solubility measurements of Borch-Jensen and Mollerup (1997) for the same oil. We can see that, for both lipids, the density increase with the rising $\mathrm{CO}_{2}$ solubility is linear up to about $25 \%$ (33\% for Venter et al. results). Above this solubility value, the density increase is sharper. This leads to the conclusion that in the first linear part, density is mainly influenced by the dissolution of $\mathrm{CO}_{2}$ while in the second part of the curve the density enhancement is mainly due to the compression effect. Hence, the dissolution of $\mathrm{CO}_{2}$ governs the density evolution for all pressures investigated at $353 \mathrm{~K}$ and up to $10 \mathrm{MPa}$ at $313 \mathrm{~K}$. At $313 \mathrm{~K}$, the range of solubility is similar for $\mathrm{CB}$ and fish oil, although $\mathrm{CB}$ is mainly composed of monounsaturated TG (C16-C18 fatty acids chain length) while fish oil is mainly composed of polyunsaturated TG (C20-C22 fatty acids chain length). It has been shown for diglycerides in literature (Sampaio de Sousa et al., 2006) that the longer the fatty acids chains, the smaller the $\mathrm{CO}_{2}$ solubility. If we suppose that it is also true for triglycerides, this would means that the unsaturations would enhance the $\mathrm{CO}_{2}$ solubility. Hence here the effect of the unsaturation degree might compensate a longer hydrocarbon chain length. 
This work $(313 \mathrm{~K}) \quad$ This work $(353 \mathrm{~K}) \quad \square$ Venter et al. (313 K) O Venter et al. (353 K) $\Delta$ Seifried et al. (313 K)

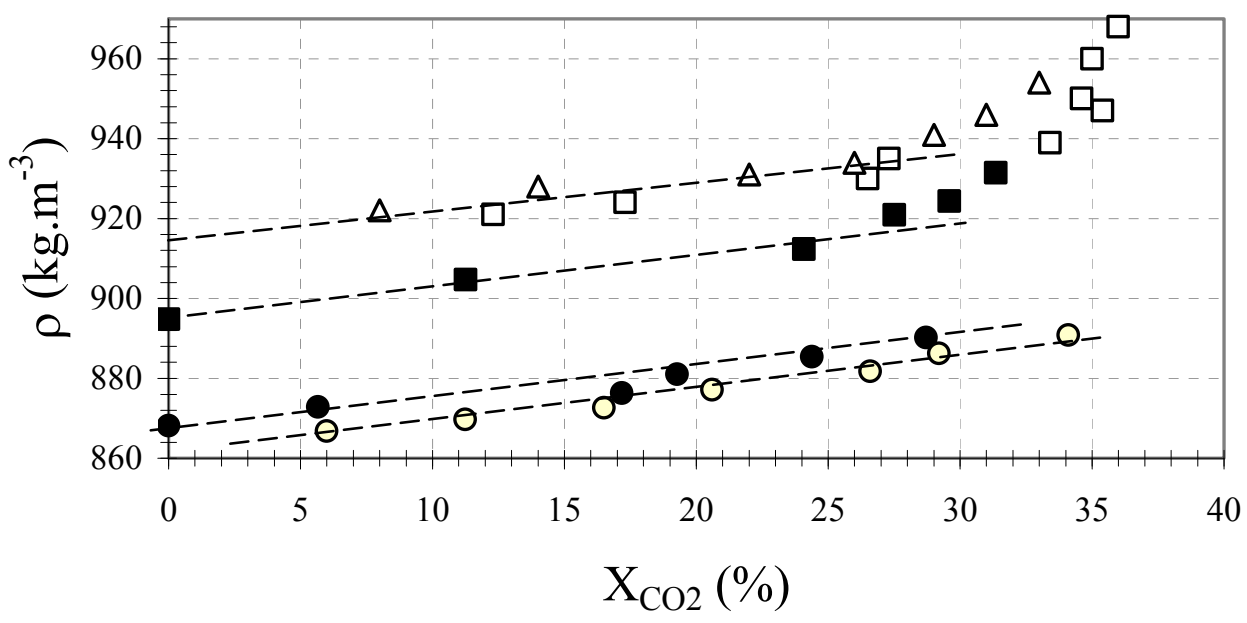

Figure 9. Comparisons of density of fats saturated with $\mathrm{CO}_{2}$ at 313 and $353 \mathrm{~K}$

The variations of density versus pressure and temperature can be represented for cocoa butter $(\mathrm{CB})$ and the $\mathrm{CO}_{2}$-saturated $\mathrm{CB}$ mixture using an empirical model as the modified Tait equation (Dymond and Malhotra, 1998):

$\rho_{f}(T, P)=\frac{\rho\left(T, P_{0}\right)}{1-C \ln \left(\frac{(B(T)+P)}{B(T)+P_{0}}\right)}$

$B(T)=B_{0}+B_{1} \cdot T+B_{2} \cdot T^{2}$

where $\rho_{f}$ is the fluid density $\left(\mathrm{kg} \cdot \mathrm{m}^{-3}\right)$ at given pressure and temperature. $B(T)$ and $C$ are fitting parameters without physical meaning. This empirical model has been used to fit experimental density measured at 313,323 and $353 \mathrm{~K}$ and for pressure ranging from $0.1\left(P_{0}\right)$ to $25 \mathrm{MPa}$ (Table 5 and curves in Figure 8).

In order to evaluate the performance of the fitting with the Tait model, the following characteristic quantities have been used:

$$
A A D=\frac{1}{N} \sum_{i=1}^{i=N}\left|100 \cdot\left(\frac{\rho_{\text {exp }}-\rho_{\text {cal }}}{\rho_{\text {exp }}}\right)\right|
$$




$$
\begin{aligned}
& \operatorname{Max} D=\operatorname{Max}\left(\left|100 \cdot\left(\frac{\rho_{\exp }-\rho_{c a l}}{\rho_{\exp }}\right)\right|\right) \\
& \text { Bias }=\frac{1}{N} \sum_{i=1}^{i=N} 100 \cdot\left(\frac{\rho_{\exp }-\rho_{c a l}}{\rho_{\exp }}\right)
\end{aligned}
$$

Table 5. Fitting parameters and characteristics quantities for density modelling

\begin{tabular}{|c|c|}
\hline Fluid & Modified Tait Equation \\
\hline & $\mathrm{C}=11.6688$ \\
& $\mathrm{~B}_{0}=7.74510 \times 10^{5}$ \\
& $\mathrm{~B}_{1}=-4.44877 \times 10^{3}$ \\
& $\mathrm{~B}_{2}=6.52325$ \\
& $\mathrm{AAD}=0.044 \%$ \\
& $\mathrm{MaxD}=0.174 \%$ \\
& $\mathrm{Bias}=2.76 \times 10^{-3} \%$ \\
\hline & $\mathrm{C}=0.05050$ \\
& $\mathrm{~B}_{0}=791.54960$ \\
$\mathrm{CB}_{1}-\mathrm{CO}_{2}$ & $\mathrm{~B}_{1}=-5.11247$ \\
& $\mathrm{~B}_{2}=0.00847$ \\
& $\mathrm{AAD}=0.044 \%$ \\
& $\mathrm{MaxD}=0.180 \%$ \\
& $\mathrm{Bias}=1.03 \times 10^{-2} \%$ \\
\hline
\end{tabular}

The average absolute deviation (AAD) characterizes the distance between the experimental points and the modelled curve. The average deviation (Bias) characterizes the quality of the distribution of the experimental points on both sides of the modelled curve. Maximum deviation (MaxD) characterizes the maximum deviation generated by the model. In this work, we programmed the Levenberg-Marquardt algorithm under Matlab ${ }^{\circledR}$. It is a very useful method for non-linear squares problem, permitting to determine the optimal combination of fitting parameters in order to minimize the deviation in relation to the experimental data. Results obtained for density fitting are satisfactory since AAD equals $0.044 \%$. Consequently, these results show that this model is relevant and can be used in this work as a reliable tool for viscosity determination of $\mathrm{CB}$ saturated with $\mathrm{CO}_{2}$. 


\subsubsection{Volumetric Expansion}

Expansion of cocoa butter with $\mathrm{CO}_{2}$ was measured at 313 and $353 \mathrm{~K}$ and the results are presented in Table 6 and Figure 12. No volumetric expansion data about $\mathrm{CO}_{2}-\mathrm{CB}$ system are available in the literature but some investigators characterized this property for other fats such as corn and palm oils (Tegetmeier et al., 2000), fish oil (Seifreid and Temmeli, 2009).

The volumetric expansion of $\mathrm{CB}$ saturated with $\mathrm{CO}_{2}$ increases with the pressure and decreases with the temperature until the inversion zone around 28 $\mathrm{MPa}$. At $353 \mathrm{~K}$, the expansion increases almost linearly until $25 \mathrm{MPa}$ and at a slower rate at higher pressures. At $313 \mathrm{~K}$ the expansion curves has a hyperbolic shape tending towards a plateau reached at around $25 \mathrm{MPa}$. Indeed, above this pressure, the volumetric expansion increases only very slightly. This is linked to the density evolution comments given previously: above $10 \mathrm{MPa}$ at $313 \mathrm{~K}$, compression effect prevails over dissolution one. As the density of both phases increases with the pressure but not at the same rate (higher for the $\mathrm{CO}_{2}$-rich phase), there is a pressure for which the densities are identical. At $313 \mathrm{~K}$ and 40 $\mathrm{MPa}$, figure 13 shows that there is no longer a "heavy" and a "light" phase indicating that the density of both phases are close enough not to have one phase on top of the other. Therefore, a phase inversion has occured at a pressure slightly lower than $40 \mathrm{MPa}$. Borch-Jensen and Mollerup (1997) observed also this phenomenon at $313 \mathrm{~K}$ and $42 \mathrm{MPa}$ for fish oil in equilibrium with $\mathrm{CO}_{2}$.

Table 6. Volumetric expansion of cocoa butter saturated with $\mathrm{CO}_{2}$ at 313 and $353 \mathrm{~K}$

\begin{tabular}{|c|c|c|c|}
\hline \multicolumn{2}{|c|}{$313 \mathrm{~K}$} & \multicolumn{2}{|c|}{$353 \mathrm{~K}$} \\
\hline P (MPa) & E (\%) & P (MPa) & E (\%) \\
\hline 5.00 & $14.17 \pm 0.45$ & 5.08 & $4.63 \pm 0.12$ \\
\hline 7.91 & $27.60 \pm 0.80$ & 8.69 & $10.88 \pm 0.26$ \\
\hline 10.09 & $32.24 \pm 0.92$ & 10.27 & $13.50 \pm 0.32$ \\
\hline 15.14 & $36.40 \pm 1.02$ & 15.08 & $22.36 \pm 0.51$ \\
\hline 20.04 & $38.35 \pm 1.06$ & 20.07 & $30.82 \pm 0.67$ \\
\hline 25.02 & $39.57 \pm 1.09$ & 25.00 & $36.67 \pm 0.78$ \\
\hline 30.09 & $40.55 \pm 1.11$ & 30.04 & $40.90 \pm 0.86$ \\
\hline 33.31 & $40.79 \pm 1.12$ & 35.07 & $44.72 \pm 0.92$ \\
\hline & & 40.15 & $47.14 \pm 0.96$ \\
\hline
\end{tabular}


- $313 \mathrm{~K}$ ○ $353 \mathrm{~K}$

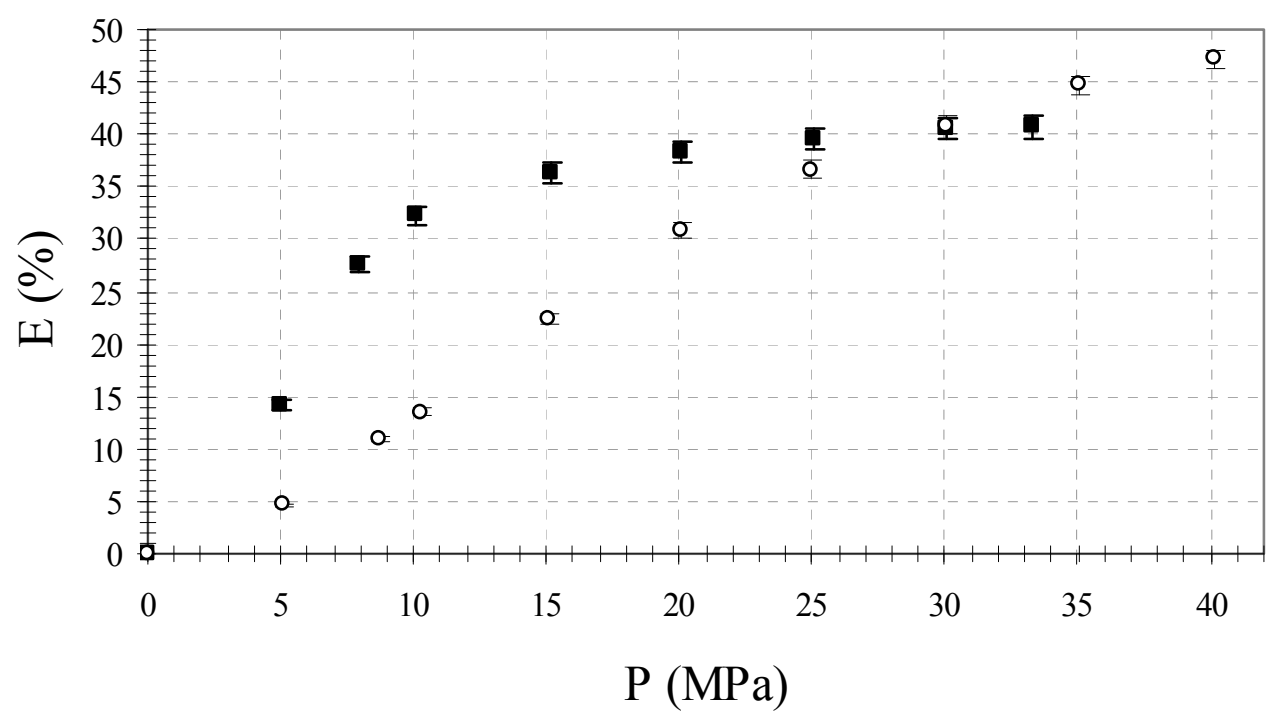

Figure 12. Volumetric expansion of $\mathrm{CB}$ saturated with $\mathrm{CO}_{2}$ as a function of the pressure at 313 and $353 \mathrm{~K}$

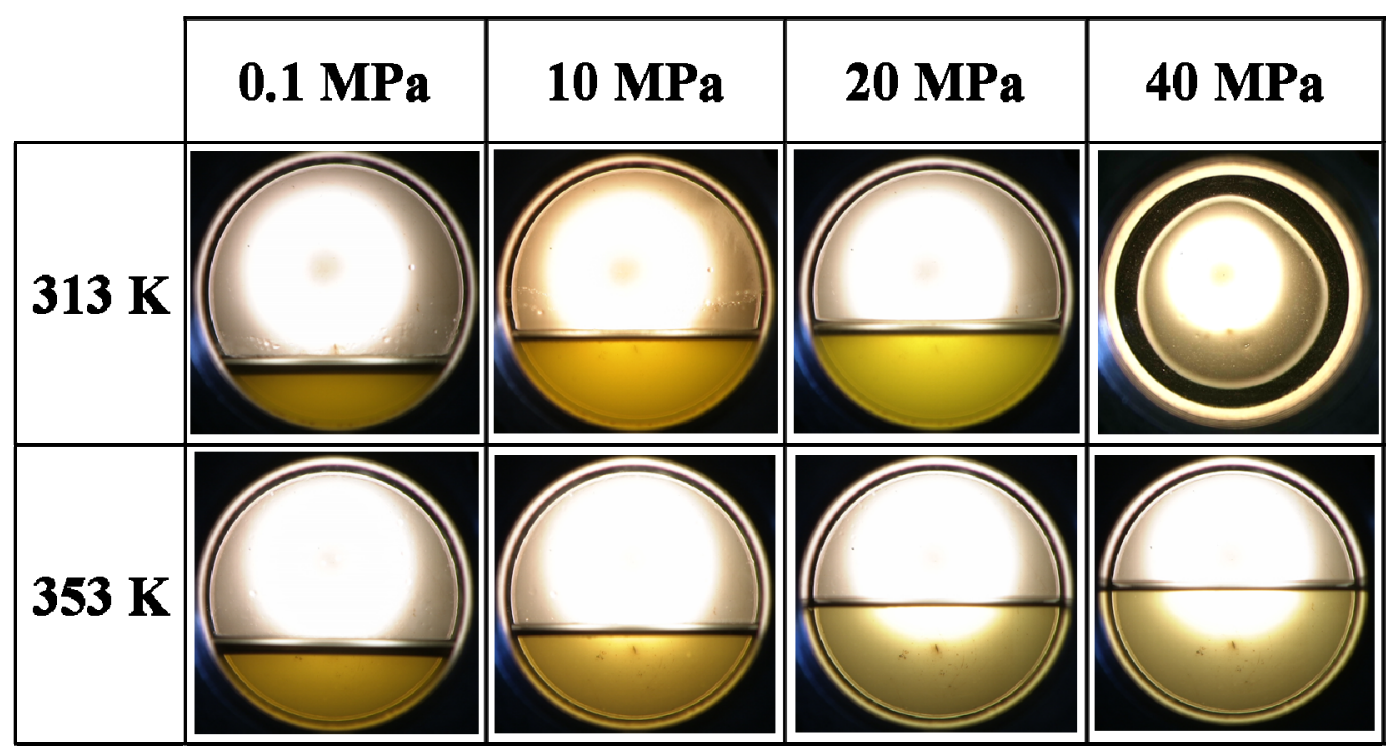

Figure 13. Phase equilibria behaviour at 313 and $353 \mathrm{~K}$ 
The volumetric expansion increases almost linearly with the $\mathrm{CO}_{2}$ solubility with a slope close to 1 (Figure 14). It means that other influences than the $\mathrm{CO}_{2}$ dissolution such as temperature effect and compression are negligible within the operating range investigated.

Rigorously, volumetric expansion is linked to the $\mathrm{CO}_{2}$ solubility and to the density of CB-rich phase $\left(\rho_{C B-C O 2}\right)$ and $\mathrm{CB}\left(\rho_{C B}\right)$ following the equation (6):

$E(\%)=\left(\frac{\rho_{C B(T, P)}}{\rho_{C B-C O 2(T, P)}}\left(\frac{1}{1-X_{C O_{2}}}\right)-1\right) \cdot 100$

Given that we have measured independently $\mathrm{CO}_{2}$ solubility and density of the mixture, we can then calculate volumetric expansion and compare it to the measured one. Density of $\mathrm{CB}$ is obtained from the Tait equation fitted on experimental values as explained above and under the same operating conditions as the $\mathrm{CO}_{2}$ solubility ones. As it is shown in Figure 15, it turns out that the calculated values are consistent with the measured ones, except for one point at 10 $\mathrm{MPa}$ and $353 \mathrm{~K}$ for which there may have been a trouble for solubility measurement: using the solubility value at the lowest deviation value, that is 15.1 $\%$, would fit better the measured expansion. At 313 and $353 \mathrm{~K}$, MD are respectively about 1.75 and $1.69 \%$. Hence, the independent measures of the different properties are consistent between them. This strengthens the reliability of our measurement methods.

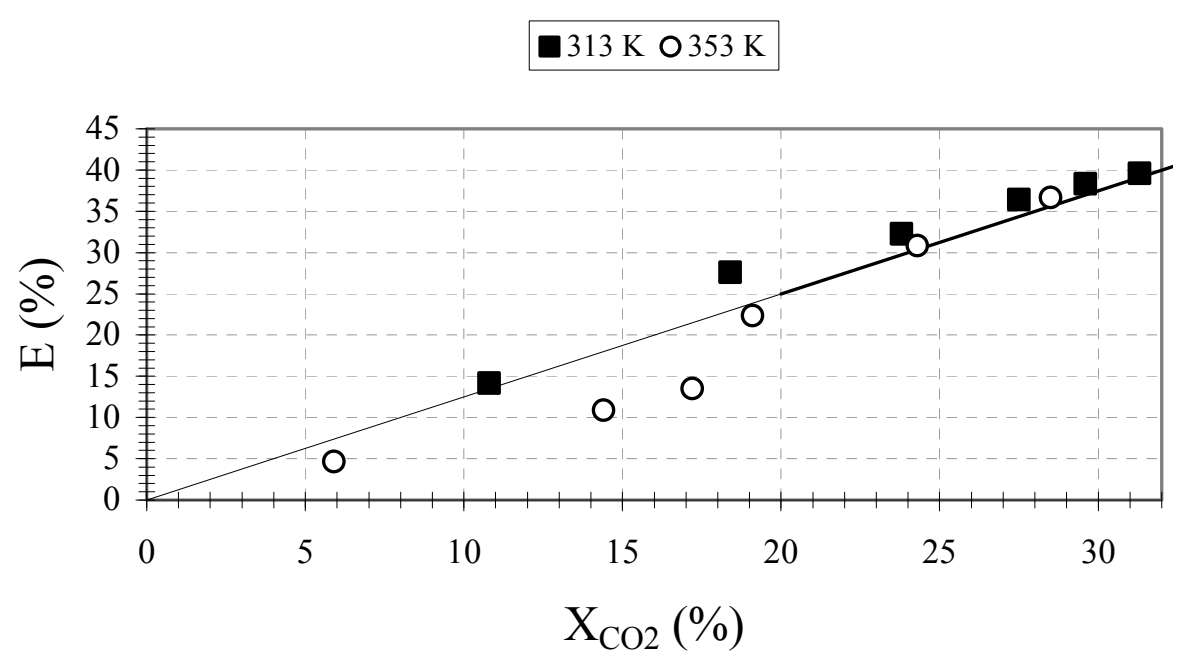

Figure 14. Evolution of the volumetric expansion of cocoa butter saturated with $\mathrm{CO}_{2}$ with the $\mathrm{CO}_{2}$ solubility 
Experimental $(353 \mathrm{~K}) \square$ Calculated $(353 \mathrm{~K}) \Delta$ Experimental $(313 \mathrm{~K}) \Delta$ Calculated $(313 \mathrm{~K})$

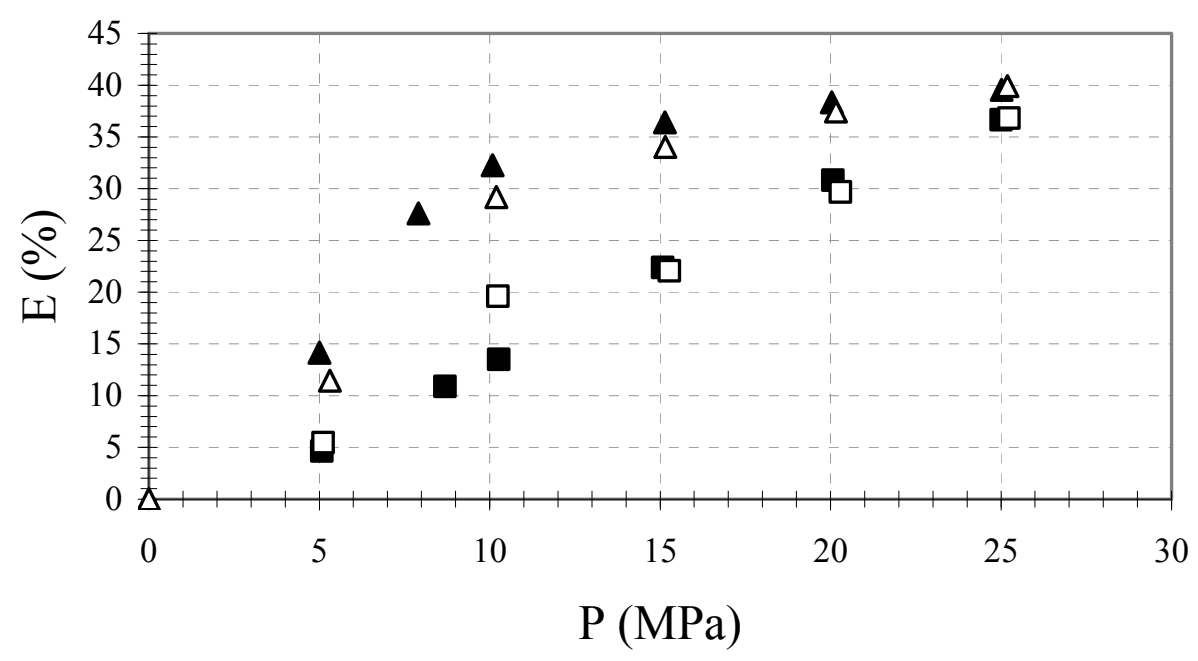

Figure 15. Comparisons of the evolution of experimental and calculated volumetric expansion with the pressure at 313 and $353 \mathrm{~K}$

\subsubsection{Viscosity}

$\mathrm{CB}$ viscosity was measured for temperature ranging from 313.15 to $353.15 \mathrm{~K}$ at atmospheric pressure and compared to results obtained with a dynamic rotational rheometer and to the literature data (Table 7). $\mathrm{CB}$ is a newtonian fluid and its viscosity decreases exponentially with temperature. Figure 16 shows the comparison between the experimental data obtained with the FBV, the rheometer $(\mathrm{MD}=1.10 \mathrm{mPa} . \mathrm{s})$ and data obtained by Venter et al. $(\mathrm{MD}=2.06 \mathrm{mPa} . \mathrm{s})$. Hence, it confirms the reliability of the technique. The viscosity behaviour of $\mathrm{CB}$ at atmospheric pressure $\left(\mathrm{P}_{0}\right)$ can be represented with the Frenkel-Andrade model (Frenkel, 1946) which assumes that viscosity is a thermally activated process:

$\mu_{C B}\left(T, P_{0}\right)=B \cdot \exp \left(\frac{E_{a}}{R T}\right)$

where $E_{a}$ represents an activation energy and $\mathrm{B}$ is a constant which are determined by using a curve fitting method with the Levenberg-Marquart algorithm. These parameters have been fitted with experimental values obtained with the FBV and are given in Figure 16. The equation 13 has been used to 
estimate the $\mathrm{CB}$ viscosity which is required for the modelling work of the CB$\mathrm{CO}_{2}$ viscosity.

Table 7. Comparison of measured and literature values of the viscosity of cocoa butter as a function of temperature at atmospheric pressure

\begin{tabular}{|c|c|c|c|}
\hline \multirow{2}{*}{ T (K) } & \multicolumn{3}{|c|}{$\boldsymbol{\mu}$ (mPa.s) } \\
\cline { 2 - 4 } & This work (FBV) & This work (Rheometer) & Venter et al. (2007) \\
\hline 313 & $45.38 \pm 0.84$ & 43.99 & 42.05 \\
\hline 323 & $32.29 \pm 0.88$ & 30.14 & 29.21 \\
\hline 333 & $22.91 \pm 0.83$ & 22.17 & 20.93 \\
\hline 343 & $17.54 \pm 1.06$ & 16.56 & 15.59 \\
\hline 353 & $12.45 \pm 0.35$ & 13.02 & 12.14 \\
\hline
\end{tabular}

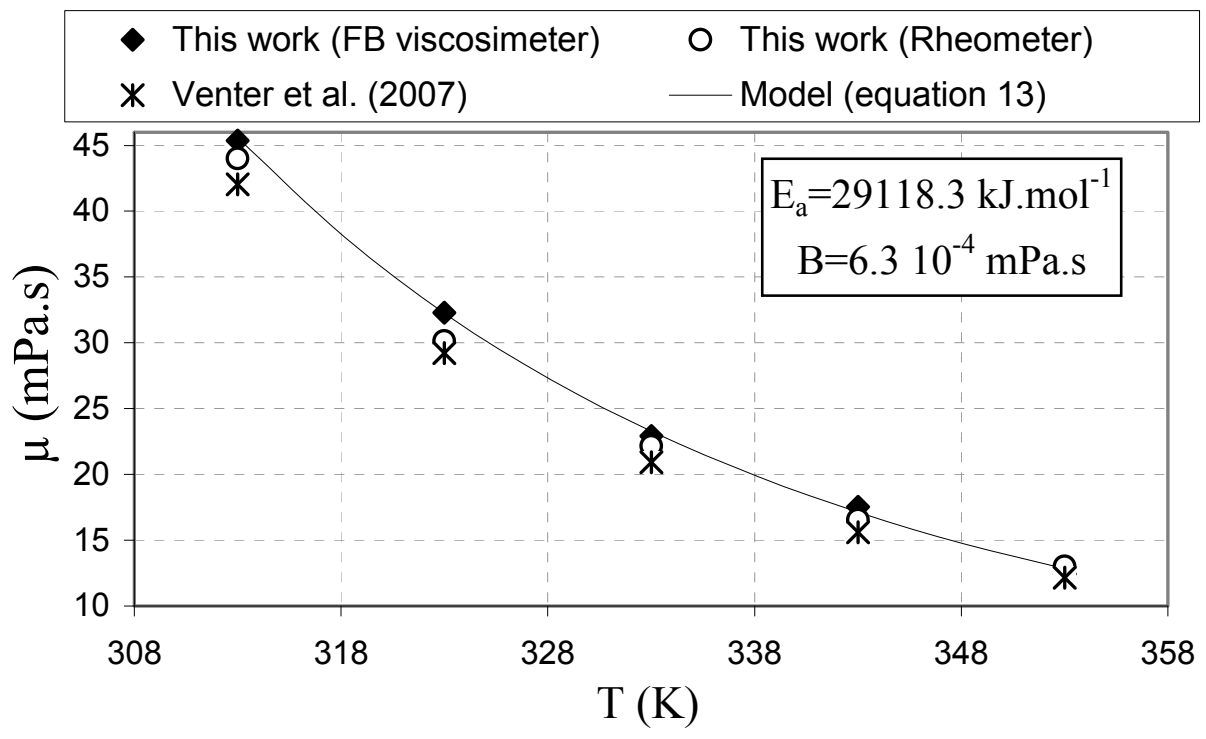

Figure 16. Viscosity measurements of cocoa butter as a function of temperature at atmospheric pressure

Viscosities of $\mathrm{CO}_{2}$-saturated $\mathrm{CB}$ mixture were measured for pressures ranging from 0.1 to $25 \mathrm{MPa}$ at 313.15 and $353.15 \mathrm{~K}$. Our data were compared to those obtained by Venter et al. who performed measurements using a vibrating quartz viscometer (Table 8). Figure 17 and 18 show that our results are in agreement with literature data: $\mathrm{MD}$ is about $1.55 \mathrm{mPa} . \mathrm{s}$ at $313 \mathrm{~K}$ and $0.63 \mathrm{mPa} . \mathrm{s}$ at $353 \mathrm{~K}$. From repeated measurements (at least three times for each data point) 
with the FBV technique, a good precision was obtained $( \pm 3 \%)$ and a good reproducibility with Relative Standard Deviation (RSD) ranging between 0.3 and $2.9 \%$.

The viscosity decreases exponentially with the pressure. The magnitude of decreasing viscosity is about $93 \%$ at $313.15 \mathrm{~K}$ and $85 \%$ at $353.15 \mathrm{~K}$. The maximal reduction is reached at approximately $15 \mathrm{MPa}$ as observed by Venter et al. This tendency is attributed to the $\mathrm{CO}_{2}$ dissolution into the melted media, which increases with the pressure as shown in Figure 18. From $15 \mathrm{MPa}$, the decrease of the viscosity slows down, so does the increase of the $\mathrm{CO}_{2}$ solubility.

Table 8 . Viscosity of cocoa butter saturated with $\mathrm{CO}_{2}$ at 313 and $353 \mathrm{~K}$

\begin{tabular}{|c|c|c|c|c|c|c|}
\hline$T(K)$ & P (MPa) & $\mathrm{v}\left(\mathrm{mm} \cdot \mathrm{s}^{-1}\right)$ & $\rho_{f}\left(\mathrm{~kg} \cdot \mathrm{m}^{-3}\right)$ & $\mu_{f}$ (mPa.s) & RSD (\%) & $\operatorname{Re}$ \\
\hline \multirow{7}{*}{313} & 0.10 & 0.39 & 894.97 & $45.38 \pm 0.84$ & 0.8 & 0.03 \\
\hline & 4.23 & 0.97 & 902.88 & $18.12 \pm 0.75$ & 1.8 & 0.19 \\
\hline & 8.45 & 2.04 & 909.89 & $8.62 \pm 0.25$ & 1.2 & 0.86 \\
\hline & 10.60 & 4.15 & 911.25 & $4.20 \pm 0.11$ & 1.1 & 3.61 \\
\hline & 15.90 & 4.87 & 920.10 & $3.58 \pm 0.19$ & 2.2 & 5.01 \\
\hline & 19.93 & 5.42 & 925.12 & $3.21 \pm 0.22$ & 2.9 & 6.25 \\
\hline & 25.22 & 5.54 & 930.93 & $3.14 \pm 0.06$ & 0.8 & 6.57 \\
\hline \multirow{6}{*}{353} & 0.10 & 1.44 & 868.18 & $12.45 \pm 0.35$ & 1.3 & 0.40 \\
\hline & 5.26 & 2.76 & 873.05 & $6.51 \pm 0.16$ & 1.0 & 1.48 \\
\hline & 10.09 & 4.71 & 876.89 & $3.80 \pm 0.15$ & 1.7 & 4.35 \\
\hline & 15.82 & 7.45 & 883.15 & $2.40 \pm 0.03$ & 0.5 & 10.98 \\
\hline & 19.94 & 8.70 & 884.14 & $2.05 \pm 0.02$ & 0.4 & 15.03 \\
\hline & 24.10 & 9.27 & 887.72 & $1.92 \pm 0.03$ & 0.3 & 17.14 \\
\hline
\end{tabular}




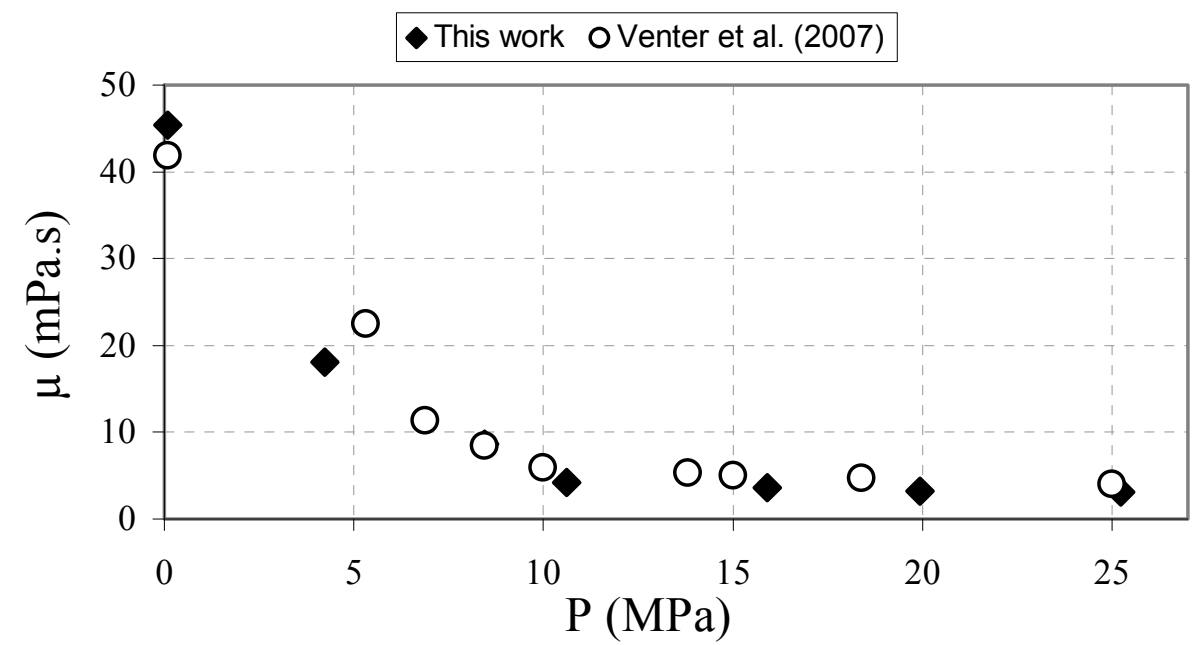

Figure 17. Viscosity measurements and literature data of cocoa butter saturated with $\mathrm{CO}_{2}$ at $313 \mathrm{~K}$

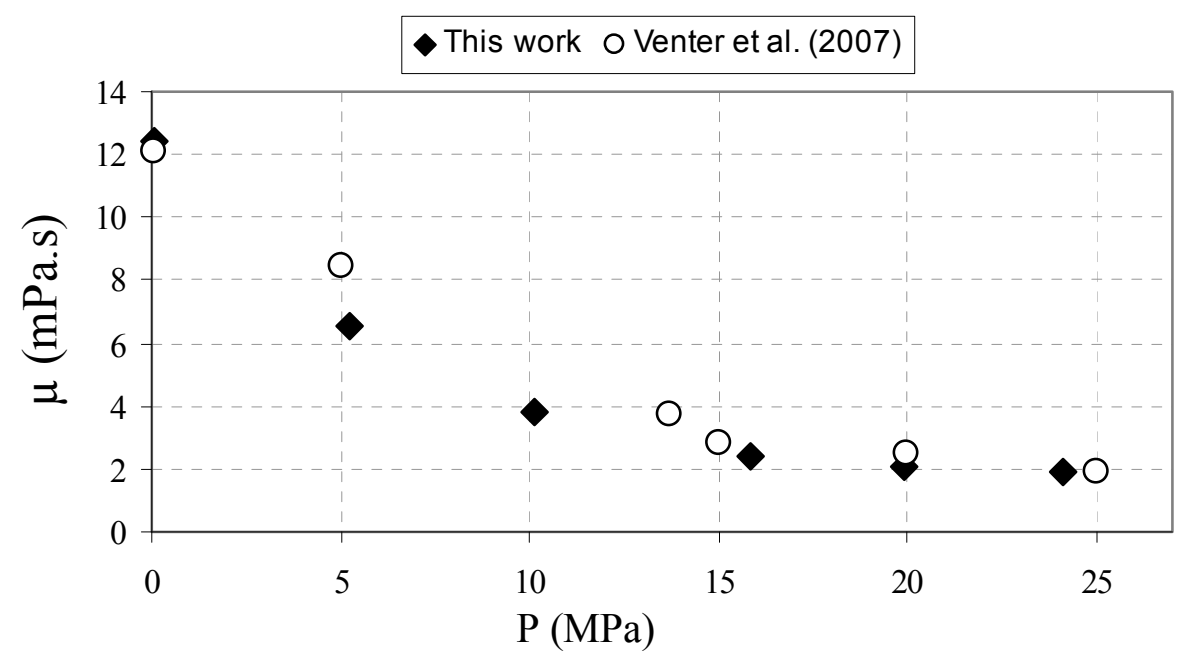

Figure 18. Viscosity measurements and literature data of cocoa butter saturated with $\mathrm{CO}_{2}$ at $353 \mathrm{~K}$

Several authors used models in order to correlate and predict the viscosity behaviour of lipids in contact with $\mathrm{CO}_{2}$ (Kashulines et al., 1991; Tuan et al., 1999; Venter et al., 2007). Tuan et al. compared the performance of the Ely and Hanley model, based on the corresponding states approach, and the Grunberg and Nissan model, which is an empirical model based on the modification of the Arrhenius equation (Grunberg and Nissan, 1949). 
The first model is predictive and correlative. Yet, it requires the knowledge of viscosity, density correlations, critical properties, acentric factor and molecular mass for a reference fluid. It may be tricky to adapt to natural lipid mixtures. Thus, generally, empirical methods are used such as Grunberg and Nissan, particularly for binary mixtures containing polar components:

$\ln \mu(T, P)=x_{1} \ln \mu_{1}+x_{2} \ln \mu_{2}+x_{1} x_{2} G_{12}(T)$

where $\mu$ is the mixture viscosity at a given pressure and temperature and the indexes 1 and 2 correspond to the mixture components, respectively $\mathrm{CO}_{2}$ and $\mathrm{CB}$. $\mu_{1}$ and $\mu_{2}$ are the viscosities of the mixture components under the same conditions. Note that the pure $\mathrm{CO}_{2}$ viscosities were taken from literature (Fenghour et al., 1998). $G_{12}$ is a binary parameter which is system-dependent and sometimes temperature-dependent (Mehrotra et al., 1996). It allows taking into account the deviations from simple additive behaviour of the mixture viscosity (Irving, 1977). $x_{1}$ and $x_{2}$ are the mass fractions of the components in the CB-rich phase at a given pressure and temperature.

In the following, we consider that the mass fraction of $\mathrm{CO}_{2}\left(\mathrm{x}_{1}\right)$ is negligible compared to 1 , the $\mathrm{CO} 2$ viscosity is negligible compared to the $\mathrm{CB}$ one and the variation of $\mathrm{CB}$ viscosity with the pressure increase is low enough to be neglected. These assumptions lead to the following relation:

$\ln \mu(T, P)=\ln \mu_{C B}\left(T, P_{0}\right)+x_{C O_{2}}(T, P) \cdot A_{12}(T)$

where $\mu_{C B}\left(T, P_{0}\right)$ is determined by equation 13 and $A_{12}$ is a binary parameter. The optimum value of $G_{12}$ and $A_{12}$ were determined using a curve fitting method with the Levenberg-Marquart algorithm. Results and performances of the two models are reported in table 9. Fitting curves of the two models are presented in the Figure 19.

Table 9. Parameters values and statistics of the viscosity correlation

\begin{tabular}{|c|c|c|c|c|}
\hline Model & Parameters & AAD (\%) & MaxD (\%) & Bias (\%) \\
\hline \multirow{3}{*}{ Grunberg \& Nissan } & $\begin{array}{c}G_{12}=-2.88(313 \mathrm{~K}) \\
G_{12}=-2.56(353 \mathrm{~K})\end{array}$ & 14.9 & 35.6 & 5.9 \\
\hline \multirow{2}{*}{ Our Model } & $\begin{array}{l}A_{12}=-9.12(313 \mathrm{~K}) \\
A_{12}=-7.87(353 \mathrm{~K})\end{array}$ & 11.4 & 24.7 & 2.4 \\
\hline
\end{tabular}


Our model is slightly more accurate to represent the mixture viscosity according to the composition in $\mathrm{CO}_{2}(\mathrm{AAD}=11.4 \%)$. Moreover, this model is simpler to use because it does not require the $\mathrm{CO}_{2}$ viscosity. The maximum deviations for both models are observed for the highest $\mathrm{CO}_{2}$ concentrations and are non-negligible. However, it turns out that the Bias value is lower for our model $(2.4 \%)$ which means that the distribution of the experimental points around the fitting curve is satisfactory. Hence, we can conclude that the model assumptions are valid for this kind of binary mixture.

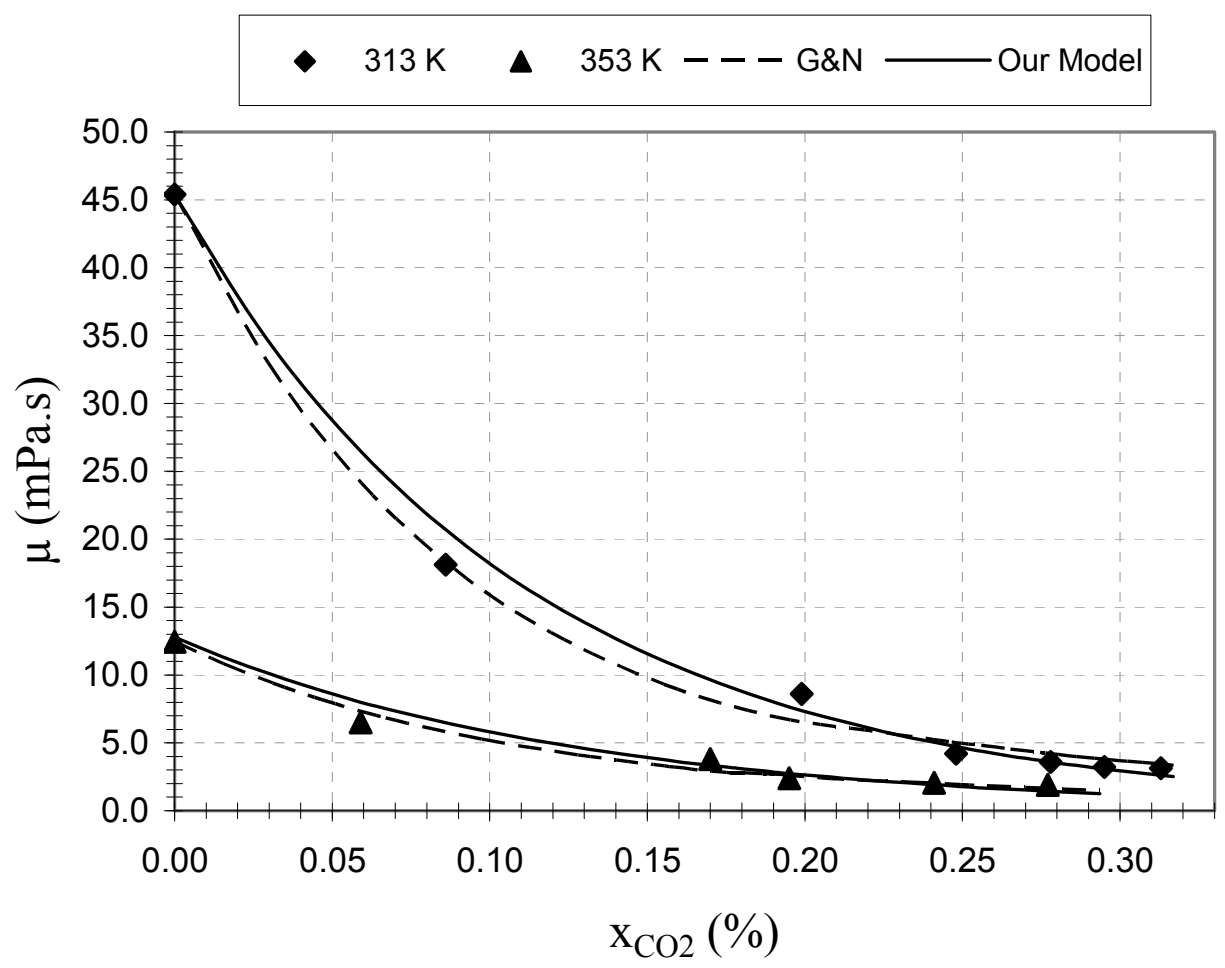

Figure 19. Viscosity of $\mathrm{CO}_{2}$-saturated cocoa butter as a function of $\mathrm{CO} 2$ solubility at 313 and $353 \mathrm{~K}$

\section{Conclusion}

A set of physical properties of $\mathrm{CO}_{2}$-saturated cocoa butter mixture have been measured, compared to literature data when available and modelled. These measurements were performed using characterization techniques that were set up and validated in a previous work. New reliable data on solubility, density, 
volumetric expansion and viscosity have been produced which complement the literature. This data could be useful for designing future lipid applications.

In this work we have validated these techniques up to $35 \mathrm{MPa}$ and $353 \mathrm{~K}$; it appears that, within these limits, they are reliable and accurate. Comparison with literature for the $\mathrm{CB}-\mathrm{CO}_{2}$ mixture has been extensively studied: all the measurements are consistent with data already published for cocoa butter of the same origin.

This work provides new experimental data on the phase equilibrium behaviour of $\mathrm{CB}$ in contact with $\mathrm{CO}_{2}$ such as the volumetric expansion and the inversion phase conditions.It is found that the solubility and density increase of $\mathrm{CO}_{2}$ involves the phase inversion at $313 \mathrm{~K}$ and $40 \mathrm{MPa}$. Volumetric expansion is proportional to the quantity of dissolved $\mathrm{CO}_{2}$, which varies linearly with pressure and is independent of temperature. This property may reach $47 \%$, and must therefore be known before designing a supercritical process, in particular for the equipment scale-up.

The density measurement method was found to be reliable $( \pm 0.60 \mathrm{~kg} . \mathrm{m}-$ $3)$. Its evolution with the $\mathrm{CO}_{2}$ solubility is comparable to that of fish oil saturated with $\mathrm{CO}_{2}$, which is mainly composed of polyunsaturated triglycerides. We modelled accurately the variations of density versus pressure and temperature with the modified Tait equation. Indeed, results obtained for density fitting are in good agreement with experimental data with an AAD of $0.044 \%$.

Our investigations with the falling ball viscometer show good reproducibility between the repeated measurements. This technique is a precision tool for viscosity measurements under high pressure $( \pm 3 \%)$. Viscosity data sets obtained both at atmospheric pressure and under high pressures are revealed to be in good agreement with the literature. We propose a new empirical relation, which correlates the viscosity of $\mathrm{CO}_{2}-\mathrm{CB}$ mixture (with $\mathrm{AAD}=12.0 \%$ ) with the $\mathrm{CB}$ viscosity at atmospheric pressure and with its composition in $\mathrm{CO}_{2}$.

Finally, the $\mathrm{CO}_{2}$ solubility turns out to be the key property governing the evolution of all other properties. For instance, the dissolution of $\mathrm{CO}_{2}$ causes a reduction in viscosity which can be as high as $90 \%$.

\section{Notation}

$\begin{array}{ll}\mathrm{A} & \text { parameter in Equation (3) } \\ \mathrm{B} & \text { parameter in Equation (3) } \\ \mathrm{E} & \text { volumetric expansion in Equation (6), \% } \\ \mathrm{P} & \text { pressure, MPa } \\ \mathrm{P}_{0} & \text { atmospheric pressure, MPa } \\ \mathrm{RSD} & \text { relative standard deviation }\end{array}$


$R S D=\frac{\sqrt{\frac{1}{N} \sum_{i=1}^{i=N}\left(x_{i}-\bar{x}\right)^{2}}}{\bar{x}} \cdot 100$

where $x$ is the measurement and $\bar{x}$ is the average between the repeted measurement.

$\mathrm{T}$ temperature, $\mathrm{K}$

$V \quad$ volume at given pressure and temperature in Equation (6), $\mathrm{ml}$

$V_{0} \quad$ volume at atmospheric pressure and given temperature in Equation (6), $\mathrm{ml}$

$X_{\mathrm{CO} 2}$ solubility of $\mathrm{CO}_{2}$ in Equation (1), \% (in mass)

$x_{\mathrm{CO} 2}$ mass fraction of $\mathrm{CO}_{2}$ in Equation (13)

\section{Greek letters}

$\rho \quad$ density, kg.m-3

$\rho_{\text {cal }} \quad$ calculated density in Equation (9), kg.m-3

$\tau \quad$ oscillation period, $\mathrm{s}$

Abbreviations

$\begin{array}{ll}\text { AAD } & \text { Absolute Average Deviation } \\ \text { Bias } & \text { Average deviation } \\ \text { CB } & \text { Cocoa Butter } \\ \text { CFD } & \text { Computational Fluid Dynamics } \\ \text { SC-CO } & \text { Supercritical Carbone Dioxide } \\ \text { FBV } & \text { Falling Body Viscometer } \\ \text { MaxD } & \text { Maximum deviation } \\ \text { MD } & \text { Mean Deviation } \\ \text { VLE } & \text { Vapour-Liquid Equilibrium }\end{array}$




\section{References}

Bhaskar A.R., Rizvi S.S.H., Bertoli C., "Cocoa butter fractionation with supercritical carbon dioxide", Proceedings of the third International Symposium on High Pressure Chemical Engineering, von Rohr P. and Trepp C. Eds. 1996, 297-302, Elsevier, Amsterdam.

Borch-Jensen C., Mollerup J., "Phase equilibria of fish oil in sub- and supercritical carbon dioxide", Fluid Phase Equilibria, 1997, 138, 1-2, 179-211.

Calvignac B., Rodier E., Letourneau J.-J., Fages J., "Development of characterization techniques of thermodynamic and physical properties applied to the $\mathrm{CO}_{2}$-DMSO mixture", International Journal of Chemical Reactor Engineering, 2009a, 7, A46

Calvignac B., Vitoux P., Rodier E., Letourneau J.-J., Aymonier C., Fages J., "Development of a falling body viscosimeter for high pressure measurements", Proceedings of the $9^{\text {th }}$ International Symposium on Supercritical Fluids, Cansell F., Mercadier J. and Fages J. Eds., ISBN 978-2-9511591-7-4, 2009 b.

Chaiseri, S., Dimick, P.S., "Lipids and hardness characteristics of cocoa butters from different geographic regions", J. of the American Oil Chemists Society, 1989, 66, 11, 1771.

Dymond J. H., Malhotra R., "The Tait equation : 100 Years on", International journal of thermophysics, 1988, 9, 6, 941-951.

Fenghour, A., Wakeham, W.A., Vesovic, V., "The Viscosity of Carbon Dioxide", J. Physical and Chemical Reference Data, 1998, 27, 31-44.

Grunberg L., Nissan A. H., "Mixture Law for Viscosity", Nature, 1949, 164, 799800 .

Irving J.B., "Viscosities of binary liquid mixtures: the effectiveness of mixture equation", In: (4th edn.), 1977, National Engineering Lab., East Kilbride, Glasgow, Scotland.

Kashulines P., Rizvil S.S.H., Harriott P., Zollweq J.A., "Viscosities of fatty acids and methylated fatty acids saturated with supercritical carbon dioxide", J. of the American Oil Chemists Society, 1991, 68, 12, 912-921. 
Kokot K., Knez Z., Bauman D., "S-L-G (Solid-Liquid-Gas) phase transition of cocoa butter in supercritical $\mathrm{CO}_{2}$ ", Acta Alimentaria, 1999, 28, 2, 197-208.

Letourneau J.-J., Vigneau S., Gonus P., Fages J., "Micronized cocoa butter particles produced by a supercritical process", Chemical Engineering and Processing, 2005, 44, 2, 201-207.

Mehrotra A. K., Monnery W. D., Svrcek W. Y., "A review of practical calculation methods for the viscosity of liquid hydrocarbons and their mixtures", Fluid Phase Equilibria, 1996, 117, 1-2, 344-355.

Perva-Uzunalic A., Skerget M., Knez Z., "Supercritical fluids for producing cocoa powder", Proceedings of the 2008 Joint Central European Congress, 2008, 1, 211 217.

Sahena F., Zaidul I.S.M., Jinap S., Karim A.A., Abbas K.A., Norulaini N.A.N., Omar A.K.M., "Application of supercritical $\mathrm{CO}_{2}$ in lipid extraction - A review", J. of Food Engineering, 2009, 95, 2, 240-253.

Sampaio de Sousa A.R., Calderone M., Rodier E., Fages J., Duarte C.M.M., "Solubility of carbon dioxide in three lipid-based biocarriers", J. Supercritical Fluids, 2006, 39(1), 13-19

Seifried B., Temelli F., "Density of marine lipids in equilibrium with carbon dioxide", J. Supercritical Fluids, 2009, 50, 2, 97-104.

Span R., Wagner W., "A New Equation of State for Carbon Dioxide Covering the Fluid Region from the Triple-Point Temperature to $1100 \mathrm{~K}$ at Pressures up to 800 MPa", J. Physical and Chemical Reference Data, 1996, 25, 6, 1509-1596.

Tegetmeier A., Dittmar D., Fredenhagen A., Eggers R., "Density and volume of water and triglyceride mixtures in contact with carbon dioxide", 2000, Chemical Engineering and Processing, 39, 399-405.

Temelli F., "Perspectives on supercritical fluid processing of fats and oils", J. Supercritical Fluids, 2009, 47, 3, 583-590.

Tuan D. Q., Zollweg J. A., Harriott P., Rizvi S. S. H., "Measurement and modeling of viscosity of supercritical carbon dioxide/biomaterial(s) mixtures", Industrial and Engineering. Chemistry Research, 1999, 38, 2129-2136. 
Venter M. J., Willems P., Kuipers N. J. M., De Haan A. B., "Gas assisted mechanical expression of cocoa butter from nibs and edible oils from oilseeds", J. Supercritical Fluids, 2006, 37, 3, 350-358.

Venter M. J., Willems P., Kareth S., Weidner E., Kuipers N. J. M., De Haan A. B., "Phase equilibria and physical properties of $\mathrm{CO} 2$ satured cocoa butter mixtures at elevated pressures", J. Supercritical Fluids, 2007, 41, 2, 195-203.

Wagner W., Pruss A., "The IAPWS formulation 1995 for the thermodynamic properties of ordinary water substance for general and scientific use", J. Physical and Chemical Reference Data, 2002, 31, 2, 387-535. 